\title{
Indicator Compounds Representative of Contaminants of Emerging Concern (CECs) Found in the Water Cycle in the United States
}

\author{
Shuangyi Zhang ${ }^{1, *}$, Stephen Gitungo ${ }^{2}$, John E. Dyksen ${ }^{3}$, Robert F. Raczko ${ }^{3}$ and Lisa Axe ${ }^{4}$ \\ 1 Shanghai National Engineering Research Center of Urban Water Resources Co., Ltd., Shanghai 200082, China \\ 2 Department of Civil \& Environmental Engineering, New Jersey Institute of Technology, \\ Newark, NJ 07102, USA; swg5@njit.edu \\ 3 SUEZ North America, Paramus, NJ 07652, USA; consult0851@gmail.com (J.E.D.); \\ bob.raczko@suez.com (R.F.R.) \\ 4 Otto H. York Department of Chemical and Materials Engineering, New Jersey Institute of Technology, \\ Newark, NJ 07102, USA; lisa.b.axe@njit.edu \\ * Correspondence: zhang_shuangyi@hotmail.com; Tel.: +86-137-6156-5785
}

check for updates

Citation: Zhang, S.; Gitungo, S.; Dyksen, J.E.; Raczko, R.F.; Axe, L. Indicator Compounds Representative of Contaminants of Emerging Concern (CECs) Found in the Water Cycle in the United States. Int. J. Environ. Res. Public Health 2021, 18, 1288. https://doi.org/10.3390/ ijerph18031288

Academic Editors: Yu-Pin Lin and Marta Otero

Received: 22 December 2020

Accepted: 29 January 2021

Published: 1 February 2021

Publisher's Note: MDPI stays neutral with regard to jurisdictional claims in published maps and institutional affiliations.

Copyright: (c) 2021 by the authors. Licensee MDPI, Basel, Switzerland. This article is an open access article distributed under the terms and conditions of the Creative Commons Attribution (CC BY) license (https:// creativecommons.org/licenses/by/ $4.0 /)$

\begin{abstract}
The presence of contaminants of emerging concern (CECs) in the aquatic environment has recently become a global issue. The very large number of CECs reported in the literature makes it difficult to interpret potential risks as well as the removal efficiencies, especially for the more recalcitrant compounds. As such, there is a need for indicator compounds that are representative of CECs detected in systems worldwide. In an effort to develop such a list, five criteria were used to address the potential for applying indicator compounds; these criteria include usage, occurrence, resistance to treatment, persistence, and physicochemical properties that shed light on the potential degradability of a class of compounds. Additional constraints applied included the feasibility of procuring and analyzing compounds. In total, 22 CECs belonging to 13 groups were selected as indicator compounds. These compounds include acetaminophen and ibuprofen (analgesic); erythromycin, sulfamethoxazole, and trimethoprim (antibiotics); diazepam and fluoxetine (antidepressants); carbamazepine (antiepileptic); atenolol and propranolol ( $\beta$-blockers); gemfibrozil (blood lipid regulator); tris(2chloroethyl)phosphate (TCEP) (fire retardant); cotinine (nicotine metabolite); atrazine, metolachlor, and N,N-diethyl-meta-toluamide (DEET) (pesticides); $17 \beta$-estradiol and cholesterol (steroids); caffeine (psychomotor stimulant); perfluorooctane sulfonate (PFOS) and perfluorooctanoic acid (PFOA) (surfactants); and iopromide (X-ray contrast agent). These thirteen groups of compounds represent CECs with the greatest resistance to treatment processes, most persistent in surface waters, and detected with significant frequency throughout the water cycle. Among the important implications of using indicator compounds are the ability to better understand the efficacy of treatment processes as well as the transport and fate of these compounds in the environment.
\end{abstract}

Keywords: contaminants of emerging concern; indicator compounds; water cycle; occurrence and usage; water and wastewater treatment; physicochemical properties

\section{Introduction}

The detection of contaminants of emerging concern (CECs) [1] in the water cycle [2-4] has raised concern, as they have been found in effluents of wastewater treatment plants, in surface water, and even in drinking water treatment systems. The U.S. Geological Survey (USGS) conducted the first reconnaissance in 2002 that demonstrated the plethora of pharmaceuticals, steroid hormones, and other non-regulated organic compounds in the environment [5]. The presence of these emerging contaminants has led to a number of studies to better understand their fate, transport, and removal. While the consequence of environmental exposure is of the utmost importance, it has received less attention. Nevertheless, studies have demonstrated occurrences in aquatic systems all over the 
world-for example, in North America [6-12], in Europe [13-18], and in Asia [19-23]. These studies reveal observations of many classes of CECs, with concentrations ranging from nanograms per liter (ng/L) to micrograms per liter $(\mu \mathrm{g} / \mathrm{L})$.

Although CECs are present in the aquatic environment at what may appear to be lower concentrations $[19,24,25]$ than observed for regulated contaminants, the large number of compounds reported in these studies makes it difficult to evaluate the impact as they involve compounds that are widely used, frequently detected, recalcitrant, as well as present as mixtures in the water cycle. Their occurrence in the effluents from the wastewater treatment plants (WWTPs) and the transport into source water for drinking water treatment facilities has led to the need to better understand the efficacy of treatment processes in degradation, transformation, and removal. Similarly, the large number of compounds makes the cost of analysis significant. Furthermore, once released, these products pose a potential threat to aquatic organisms, water resources, and human health [26-28]; studies have demonstrated, for example, that CEC exposure resulted in antibiotic resistance and intersex in fish, and hyperglycemia and hepatic histological abnormalities in mice [29-31]. Human health risks have also been evaluated in a number of studies [32-37]. Given the vast number of these compounds, using indicator compounds that are representative of CECs in water systems would be highly advantageous in tracking their behavior in the environment and in evaluating their removal through pilot plant studies and full-scale treatment plants; a further benefit is the potential for reducing the extent and cost of analysis.

The objective of this paper is to demonstrate that based on studies conducted to date, indicator compounds can be developed based on the vast array of CECs that are detected throughout the water cycle in the United States and recalcitrant to the treatment processes. These compounds are ones that can then be applied in further studies to address transport and fate in the environment as well as treatment efficacy in water and wastewater plants. The rationale for selecting criteria will be reviewed. Based on the criteria, indicator compounds are delineated with the expectation that they are representative of wide-scale use and occurrence, resistant to treatment, persistent in the environment, and the range of physiochemical properties; again, these compounds would aid in tracking CECs and would reduce the number of CECs to be analyzed.

\section{Criteria for Selecting Indicator Compounds}

Based on an exhaustive literature review, criteria that reflect issues related to CEC observances in the water cycle include usage, frequency of detection, resistance to treatment, persistence, and physicochemical properties (Figure 1). Usage of CECs directly corresponds to the probability of occurrence in the environment. Occurrence of CECs in the aquatic environment poses a potential risk to human health and the associated ecosystems. Resistance to treatment processes characterizes whether a CEC is removed through WWTPs and discharged to the surface water that may serve as the source water for water treatment plants (WTPs), while CECs that go untreated in WTPs reflect their potential presence in drinking water, which may pose potential human health risks. Persistence demonstrates the stability of the CECs as well as the resistance to degradation in the environment, which may pose potential risks to aquatic organisms. Some CECs that are recalcitrant through treatments and persistent in the environment may not be widely used or frequently studied but are always detected when analyzed; these compounds cannot be neglected and need to be considered. Physicochemical properties such as structure, $\mathrm{K}_{\mathrm{ow}}$, $\mathrm{K}_{\mathrm{oc}}, \mathrm{k}_{\mathrm{O} 3}$, and solubility determine the behavior of the CECs during treatment processes and in the environment and are therefore related to their fate during environment transport. In the following sections, these five criteria are examined with respect to CECs and the development of indicator compounds. 


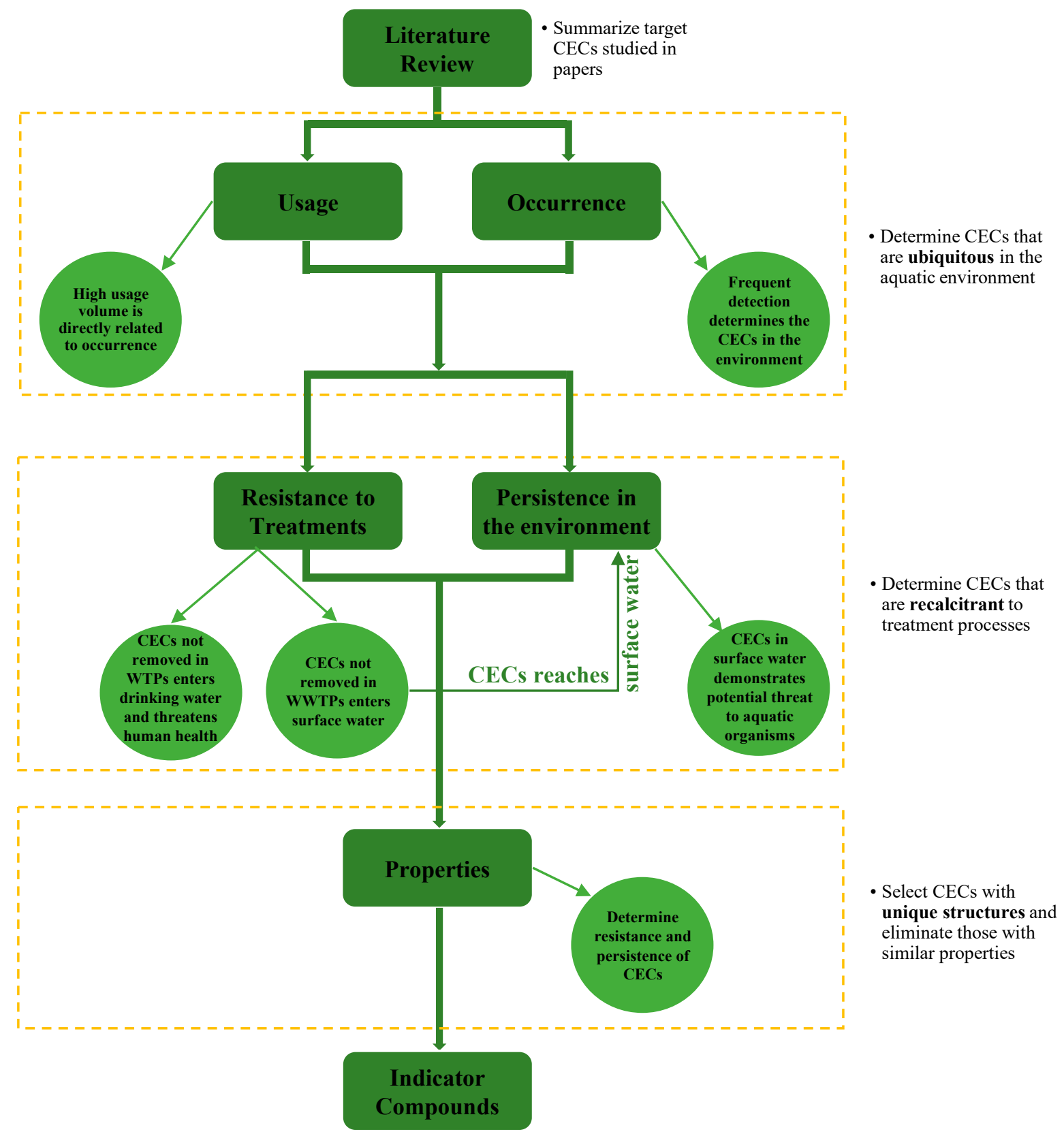

Figure 1. Criteria and flow for identifying indicator compounds.

\section{Usage and Occurrence of CECs in the United States}

\subsection{Usage of CECs}

CECs refer, in general, to any product used by individuals for personal health or cosmetic reasons or used in the agricultural industry to enhance plant or animal growth and health. CECs comprise a diverse collection of thousands of chemical substances, including prescription and over-the-counter therapeutic medications, veterinary drugs, fragrances, cosmetics, and pesticides. Because of the significant use and sources of CECs, they have been present in water and the environment for as long as humans have been using them [38]. CECs enter WWTPs through human excrement [39], inappropriate disposal into sewage systems such as flushing unused medications in toilets (and other drains), runoff and infiltration from agriculture [40,41], as well as disposal from hospitals [42-45]. Because of the wide use of CECs and resulting release into the water cycle, they have been observed over the last decade worldwide and pose a potential threat to the environment. 
The occurrence of CECs in WWTPs and the environment is greatly dependent on their usage, which can be reflected by sales and dispensed prescriptions.

Drug sales in the U.S. grew annually from 2006, except in 2012. For example, the total spending increased by $13.1 \%$ to USD 373.9 billion in 2014 compared to 2013 and went up by $12.2 \%$ from 2014 to 2015 [46,47]. The number of prescriptions dispensed from retail channels grew by roughly $1.0 \%$ from 2014 to 2015 and $2.1 \%$ between 2013 and 2014 . A total of 4.4 billion prescriptions were dispensed in 2015. Clearly, the large usage of pharmaceuticals has a potentially significant impact when excreted and not removed in WWTPs.

Among the top therapeutic classes by U.S. sales and dispensed prescriptions, lipid regulators, antidepressants, analgesics, $\beta$-blockers, antiepileptics, and antibiotics are of concern as they are the most frequently detected pharmaceutical classes in aqueous systems. Antidepressants were the most dispensed prescription in 2011 (264 prescriptions) (Table S1), attaining the seventh highest number of sales in that year (Table S2). Lipid regulators were ranked second in prescriptions dispensed, growing annually from 233 million in 2007 to 260 million in both 2010 and 2011, and ranking third in total sales. The usage of analgesics increased annually from 2007, totaling 244 million prescriptions in 2010 and 238 million in 2011, ranked third among all therapeutic classes and 10th based on sales. Beta-blockers are also widely used, ranking sixth, with 161 million prescriptions in 2011. Antiepileptics were 10th among the top therapeutic classes dispensed, totaling 128 million prescriptions in 2011, with its sales ranked 16th due to the high demand. The usage of antibiotics ranked 18th and totaled 69 million prescriptions in 2010. Not surprisingly, among pharmaceuticals, the following drugs are the most widely prescribed: lipid regulators, antidepressants, analgesics, $\beta$-blockers, antiepileptics, and antibiotics.

Contrast media agents represent a category of CECs that are widely used in hospitals. North America shared approximately $46 \%$ of the global market of contrast media agents in 2016 [48]. Among the sales of all types of contrast media in the United States, iodinated contrast media agents (ICMs) shared nearly 70\% sales in the market, registering the greatest market size. Due to their wide use, ICMs have been detected in WWTP effluents, source water, and drinking water [49-51].

In addition to medical-related CECs, pesticides are another category of CECs that are frequently used and therefore found in aquatic environments [52]. In the U.S., pesticides applied totaled approximately 1.1 billion pounds in both 2006 and 2007 [53]. Atrazine has been ranked first in agriculture use for a number of years (1987 to 1999) [54] (Table S3). As a result, among the most widely used pesticides, atrazine and metolachlor were most frequently detected in the water cycle $[5,49,51,55-58]$ and strongly related to agricultural land use [52]. Agriculture contributes $70 \%$ to $83 \%$ of pesticide usage in the U.S. [53] and expected runoff from the agricultural areas has been observed as the predominant source of pesticides in surface waters [59-62]. Usage of CECs is an indicator of estimated release into the environment. Usage is directly related to occurrence in aquatic environments.

\subsection{Occurrence of CECs in Wastewater}

Studies have been conducted on the occurrence of CECs in wastewater across the U.S. (Figures S1-S14) $[6,9,10,12,49,56,63-79]$. The most frequently reported classes include analgesics, antibiotics, antidepressants, antiepileptics, antihypertensions, antiseptics, $\beta$-blockers, lipid regulators, CEC metabolites, pesticides, psycho-stimulants, and steroids (Figure 2 and Figure S1). Acetaminophen, diclofenac, ibuprofen, and naproxen were the most detected analgesics (each reported in more than eight studies), with acetaminophen found in all samples collected from WWTP influents (Figures S1 and S2). The greatest concentrations were observed for acetaminophen, ibuprofen, naproxen, and salicylic acid, ranging from 370 to $218,000 \mathrm{ng} / \mathrm{L}$; these concentrations are one to three orders of magnitude greater than other investigated analgesics (i.e., brompheniramine, codeine, diclofenac, indomethacin, and mefenamic acid) (Figure S2). The ubiquity and influent concentrations of analgesics observed are consistent with prescriptions dispensed and the overall sales 
(Tables S1 and S2). Usage is a predictor of occurrence in wastewater influents, as up to $95 \%$ of pharmaceuticals taken may be excreted $[39,44,80]$. Lienert et al. (2007) studied 42 pharmaceuticals from 22 therapeutic classes and found that as much as $88 \%$ of the parent dug was excreted via urine and as much as $90 \%$ via feces [39]. For the metabolites, $0-100 \%$ was excreted via urine and $0-34 \%$ via feces [39]. Specifically, the percent excretion on average for acetaminophen is $83 \%, 16 \%$ to $51 \%$ for diclofenac, and $5 \%$ to $100 \%$ for ibuprofen $[39,80,81]$ (Table S4). These results confirm that a significant percentage of pharmaceuticals used today are excreted through urine and feces, which enter the municipal wastewater streams.

Similarly, antibiotics are the most frequently studied class, with sulfamethoxazole reported in 11 studies and trimethoprim found in seven studies (Figures S1 and S4). The influent concentrations range from 14 to $3905 \mathrm{ng} / \mathrm{L}$ for sulfamethoxazole and from 220 to $1140 \mathrm{ng} / \mathrm{L}$ for trimethoprim; these peak concentrations are approximately ten times greater than other antibiotics (Figures S1 and S4). With the total excretion as great as $98 \%$ for sulfamethoxazole [39] and 40-69\% for trimethoprim [81] (Table S4), the average detection frequency in WWTP influent was 100\% for both compounds (Figure S1 and Table S5).

Another frequently detected CEC class is antidepressants. Eight out of 13 antidepressants have been detected in 100\% of WWTP influents sampled (concentrations range from 2.3 to $609 \mathrm{ng} / \mathrm{L}$ ) (Figure S5), which is not only consistent with their usage across the U.S. (the most prescribed therapeutic class and the seventh based on sales) (Tables S1 and S2), but also relates to their excretion. For example, the most investigated antidepressants, diazepam (reported in four studies) and fluoxetine (reported in six studies), are excreted on average at $85 \%$ and $71 \%$, respectively, including the excretion of the parent drug and metabolites [39] (Table S4). The occurrence of the CECs in the influents to WWTPs is strongly related to their usage and total excretion. Other CECs that were detected in 100\% of the influent samples include carbamazepine (antiepileptic), diltiazem (antihypertension), atenolol and propranolol ( $\beta$-blockers), gemfibrozil (lipid regulator), and caffeine (psychostimulant) (Figure S1), which are widely used (Tables S1 and S2) with high excretion (Table S4).

\subsection{Occurrence of CECs in Surface Water}

With incomplete removal of CECs in the WWTPs, wastewater discharges are the main source of their occurrence in surface water [58,63,82-85]. Bartelt-Hunt et al. (2009) compared the concentrations of 19 pharmaceuticals in the surface water that were sampled upstream and downstream of the WWTP discharges [63]. Acetaminophen, azithromycin, carbamazepine, sulfadimethoxine, sulfamethazine, sulfamethoxazole, and thiabendazole that were not detected in the upstream samples were found at concentrations ranging from 153.2 to $4679 \mathrm{ng} / \mathrm{L}$ in the receiving surface water. Concentrations of caffeine, DEET, and diphenhydramine were observed to be two orders of magnitude greater in the downstream samples. Significantly greater CEC concentrations in the downstream samples than those observed in the upstream samples demonstrate that WWTP effluents are a significant source for the downstream surface waters. As also observed in a number of studies, the most reported groups of CECs in effluent samples reveal influents to WWTP as the source (Figure S1). With incomplete removal through existing WWTP treatment processes and the release to surface water, CECs will not only be detected but may also be persistent in the environment; however, this will depend on the compound's physicochemical properties (Figure S15).

Occurrence of CECs in the water cycle is impacted by runoff from agriculture as well $[52,81]$. Kim and Carlson (2006) examined the occurrence of three veterinary antibiotics (i.e., monensin, salinomycin, and narasin) in samples collected from the surface water close to an agricultural area during low-runoff (monthly mean stream flow 3.5 to $9.2 \mathrm{~cm}$ ) and high-runoff (monthly mean stream flow 0.2 to $2.3 \mathrm{~cm}$ ) conditions [86]. Concentrations ranged from below detection to $13 \mathrm{ng} / \mathrm{L}$ during the low-runoff period and increased to up to $36 \mathrm{ng} / \mathrm{L}$ during the high-runoff period. After a rain event with accumulated 
precipitation exceeding $24 \mathrm{~mm}$ in $48 \mathrm{~h}$, Matamoros et al. (2012) observed an increase in herbicide/pesticide concentrations in a river receiving runoff from the agricultural fields [87]. For example, the concentration of mecoprop increased from less than $200 \mathrm{ng} / \mathrm{L}$ to approximately $1500 \mathrm{ng} / \mathrm{L}$. As a result, herbicides, pesticides, and veterinary antibiotics enter the water cycle through agricultural practices.

Seasonal variation in the occurrence of CECs in surface water also needs to be considered. Compared to the winter season (dry season), CEC concentrations are lower in summer (wet season) by more than $50 \%$, which is attributed to dilution from increased precipitation with higher temperatures [57]. Elevated temperatures may result in transformation of CECs [88]. Padhye et al. (2014) studied the impact of precipitation and dilution on a surface water serving as a source for potable water utilities and potentially not affected by anthropogenic activities [57]. Despite the reduced concentrations observed in the summer months, 20 CECs were at least detected once in the surface water while atrazine, DEET, carbamazepine, clarithromycin, erythromycin, sulfamethoxzole, trimethoprim, metoprolol, nonyphenol, and TCEP were detected in $88 \%$ of the samples, reflecting their persistence. It is clear that population density in the vicinity of surface water is considered to be another impact factor in the occurrence of CECs [89]. Other studies [52,90] have demonstrated that concentrations of CECs in water bodies adjacent to heavily populated areas were observed to be two to 10 times greater than those observed in pristine areas.

In summary, a number of studies have demonstrated the occurrence of CECs in surface water [5,57,58,63,82-86,88-102] (Figures S15-S22). The most reported classes include analgesics, antibiotics, antidepressants, antiepileptics, antihypertensions, metabolites, pesticides, plasticizers, psycho-stimulants, steroids, and surfactants (Figure 2 and Table S6). Acetaminophen, ibuprofen, and naproxen were the most frequently studied analgesics, with average detection frequency ranging from 18\% to 33\% (Figure S15). Of antibiotics, sulfamethoxazole and trimethoprim were most frequently detected (Figure S15), while the sulfamethoxazole concentrations were one to four orders of magnitude greater than the other antibiotics (Figure S17). Their occurrence in surface water was strongly correlated to the concentrations in WWTP effluents (Figures S4 and S17). Carbamazepine is the most reported antiepileptic, with a detection frequency of 69\% (Figures S1 and S15), suggesting it is not only resistant to treatment processes but also possibly persistent in the environment. Recently, per- and polyfluoroalkyl substances (PFAS) have gained more attention for their persistence in surface water. Among the large number of PFAS, PFOA and PFOS are the two most reported and researched substances [95]; their concentration is as great as approximately $10^{9} \mathrm{ng} / \mathrm{L}$ in the surface water near a carpet industry area in Georgia [97]. The average detection frequencies across the U.S. surface water are $94 \%$ and 64\% for PFOA and PFOS, respectively (Figures S15 and S22), suggesting their persistence in the environment, which may result from historic release, ongoing discharge, or the lack of degradation [95]. The antimicrobial triclosan, fire retardant TCEP, pesticide DEET, and psycho-stimulant caffeine are the most studied compounds in their classes and were detected at similar frequencies in samples collected from WWTP effluents $(62.5 \%$ to $85 \%)$ and surface water (53\% to $80 \%$ ) (Figures S1 and S15). Other frequently studied CECs include the antidepressant fluoxetine, the blood lipid regulator gemfibrozil, the nicotine metabolite cotinine, the plasticizer bisphenol-A, and the steroid estrone. The occurrence of CECs in surface water indicates their persistence and presence in source water for drinking water treatment plants, which then raises the issue of potential adverse effects on human health from individual as well as mixtures of CECs. 


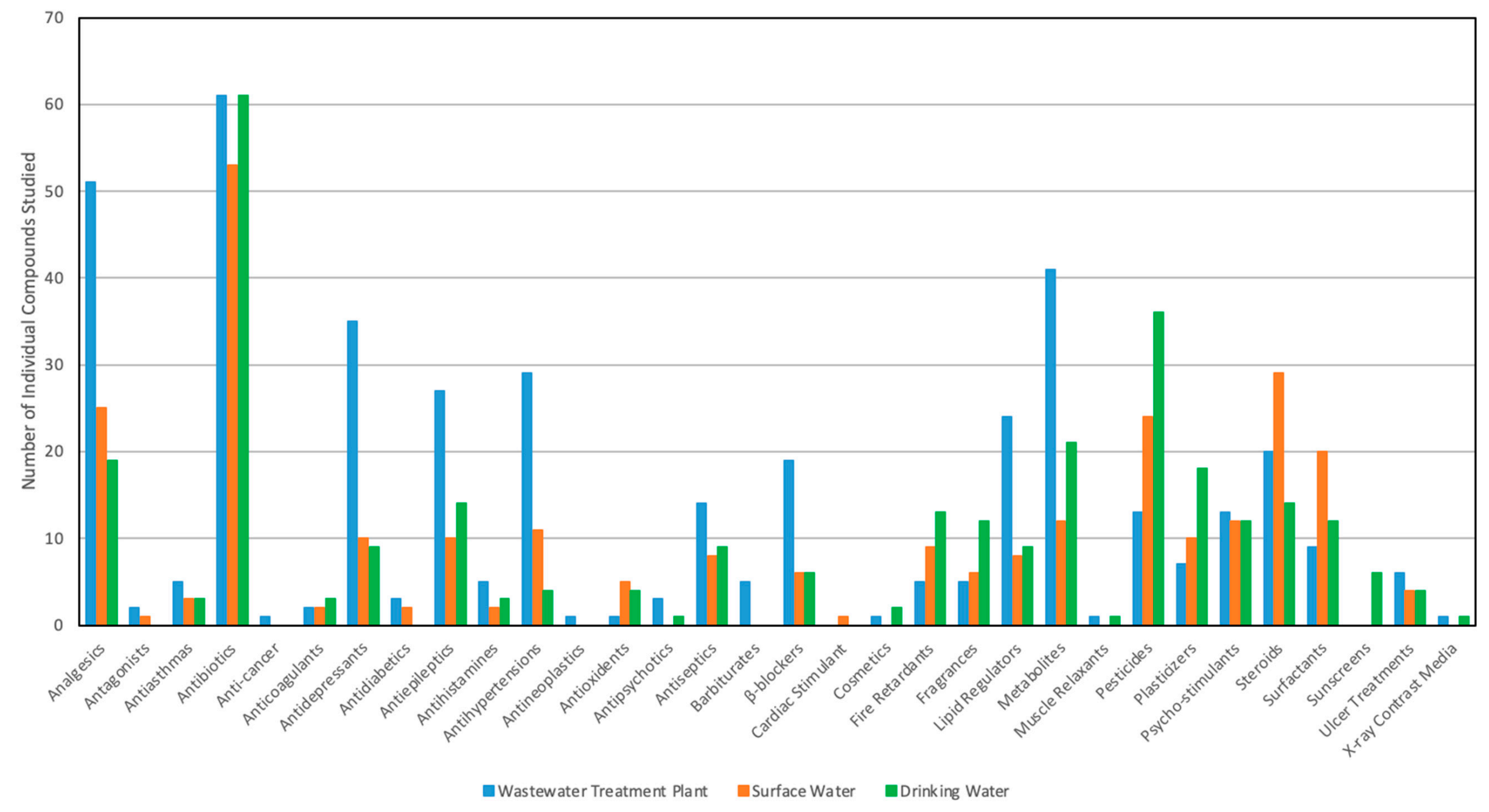

Figure 2. Number of individual compounds studied in each CEC class (data from Tables S5-S7). 


\subsection{Occurrence of CECs in Source Water and Finished Drinking Water}

The occurrence of CECs in drinking water is of the utmost importance as it leads to direct exposure in human beings. Similar to surface water, the occurrence of CECs in the source water for WTPs is affected by upstream discharges from WWTPs $[50,84,103,104]$ as well runoff from agriculture [51]. On the other hand, the occurrence of CECs in finished drinking water is dependent on the removal efficacy in WTPs, namely their resistance to treatment $[57,104]$. A number of studies have evaluated occurrence in source water and finished drinking water $[50,51,55,57,84,103-107]$. The most frequently observed classes in these systems included analgesics, antibiotics, antiepileptics, fire retardants, fragrances, CEC metabolites, pesticides, plasticizers, psycho-stimulants, steroids, and surfactants (Figure 2 and Table S7). Among 131 investigated CECs (Table S7), 22 were reported in more than four studies (Figures S23-S32) [50,51,55,57,84,95,98,103-110].

Compared to the wastewater and surface water, much lower detection frequencies have been reported in source water and finished drinking water (Figure S23). For example, of 29 antibiotics investigated in drinking water $[51,57,103,104]$, only nine were detected in source water samples and four (clarithromycin, erythromycin, sulfamethoxazole, and trimethoprim) in finished drinking water (Figure S25). Similar trends were observed for fragrances, lipid regulators, and steroids, where less than $25 \%$ of the investigated compounds were detected in both source water and drinking water samples.

For CECs frequently reported in sampled source water, concentrations have been generally less than $1000 \mathrm{ng} / \mathrm{L}$; exceptions included acetaminophen, ibuprofen, carbamazepine, and bisphenol-A, with the maximum concentration observed greater than $1500 \mathrm{ng} / \mathrm{L}$ (Figure S23). Compared to the source water samples, concentrations in finished drinking water are generally less than $100 \mathrm{ng} / \mathrm{L}$, with the exception of ibuprofen, carbamazepine, triclosan, TCEP, nonylphenol, metolachlor, bisphenol-A, caffeine, and PFOA (Figure S23). The lower concentrations reported in the sampled finished drinking water compared to the source water reveal some degree of removal in WTPs. Nevertheless, CECs are frequently detected in finished drinking water for a number of classes, including the antibiotics, antidepressants, antiepileptics, fire retardants, fragrances, the nicotine metabolite cotinine, pesticides, the psycho-stimulant caffeine, and surfactants (Figure S23). As a result, these compounds may be resistant to conventional treatment processes in WTPs and their removal efficiencies need to be evaluated.

Furthermore, the high frequency of detection (Tables S6 and S7) demonstrates persistence in aquatic environments. For example, the steroid cholesterol was only investigated in two studies; however, its average frequency of detection in surface water samples was $90 \%$, suggesting little to no degradation in the systems (Figure S22). Similarly, for the antibiotic erythromycin and the $\beta$-blocker metoprolol, the average frequencies are $59 \%$ and $100 \%$, respectively, in surface water samples (Figures S17 and S19), while the detection frequency of surfactants PFOA and PFOS was more than 50\% in the source water and the steroid estrone was detected in 77\% of source waters sampled (Figures S31 and S32). Persistence in the aquatic environment therefore is an important criterion for determining what CECs make their way to the tap and are candidate indicator compounds.

\section{Efficacy of Treatment Technologies}

\subsection{Removal Efficacy in WWTPs}

As WWTPs are not designed to treat CECs, their removals are limited. For example, removals through primary clarification are reported to be less than $36 \%[69,75,111,112]$, while no reductions were reported for diclofenac, trimethoprim, carbamazepine, diltazem, propranolol, and caffeine in this unit process (Table 1a) [69,79].

Secondary biological treatment processes such as conventional activated sludge, trickling filters, and moving bed biofilm reactors (MBBRs) address the biochemical oxygen demand, chemical oxygen demand, nitrogen, and phosphorus [63,72] and are not efficient in treating CECs. For example, Bartelt-Hunt et al. (2009) investigated the effluent concentration of sulfamethoxazole in WWTPs that employed trickling filters [63]. An average 
effluent concentration of $141.4 \pm 22.3$ was observed. Other studies [69,111,113,114] have reported removals of less than $69 \%$ for sulfamethoxazole and less than $5 \%$ for trimethoprim using activated sludge, while their removals in MBBRs ranged from $0 \%$ to $36 \%$ (Table 1a). Because of the low removal efficacies, average detection frequencies for the most reported antibiotics, sulfamethoxazole and trimethoprim, were $88 \%$ and $43 \%$, respectively. The most reported antidepressants are diazepam and fluoxetine, with detection frequencies of $71 \%$ and $38 \%$ in the effluent samples, respectively. This occurrence is consistent with the relatively low removal efficacies of $41 \%$ to $55 \%$ for diazepam and $72 \%$ for fluoxetine (Table 1b). Carbamazepine is the most studied antiepileptic, with a detection frequency of 100\% in WWTP influent samples and 90\% in sampled effluents (Figures S1 and S6). A number of studies have reported that carbamazepine is a recalcitrant compound for existing WWTPs, with removals of less than $10 \%$ through activated sludge and less than $11 \%$ through MBBRs $[75,113,115,116]$ (Table 1a). Other recalcitrant CECs in the WWTPs include the antihypertension diltiazem and $\beta$-blockers atenolol and propranolol, with total removal efficacies of less than 50\% in the WWTPs (Table $1 \mathrm{~b}$ ). The advanced treatment processes such as activated carbon and membrane technologies may improve their removals; however, these processes may not be sufficiently effective to remove the vast array of CECs from the wastewater to desired levels. For example, Khanzada et al. (2020) reported CEC removals ranging from poor $(<20 \%)$ to fair $(40-70 \%)$ in ultrafiltration and good $(70-90 \%)$ to excellent $(>90 \%)$ in activated carbon and nanofiltration [117]. The low removals result in their presence in effluents and surface water.

Studies to date have demonstrated that wide-scale usage results in occurrence throughout the water cycle, which then impacts aquatic ecosystems (Figure 1). The vast array of the recalcitrant CECs and their persistence in the environment pose potentially adverse effects through exposure to the individual compounds as well as the extensive mixtures.

Table 1. Removal efficacy of CECs in WWTPs.

\begin{tabular}{|c|c|c|c|c|c|}
\hline \multicolumn{6}{|l|}{ (a) Unit Processes } \\
\hline Class & Compound & $\begin{array}{l}\text { Clarification } \\
{[69,75,111,112]}\end{array}$ & $\begin{array}{l}\text { Activated Sludge } \\
{[69,111,114,118-120]}\end{array}$ & $\begin{array}{c}\text { MBBR } \\
{[81,113,121]}\end{array}$ & Filtration [69] \\
\hline \multirow[t]{4}{*}{ Analgesic } & Acetaminophen & $1-8 \%$ & $92-99 \%$ & - & $99 \%$ \\
\hline & Diclofenac & $0 \%$ & $0-5 \%$ & - & - \\
\hline & Ibuprofen & $0-32 \%$ & $71-99 \%$ & $94 \%$ & - \\
\hline & Naproxen & $9 \%$ & $56-99 \%$ & $70-80 \%$ & - \\
\hline \multirow{2}{*}{ Antibiotic } & Sulfamethoxazole & $17-34 \%$ & $0-69 \%$ & $0 \%$ & $89 \%$ \\
\hline & Trimethoprim & $0 \%$ & $0-5 \%$ & $36 \%$ & - \\
\hline \multirow{2}{*}{ Antidepressant } & Diazepam & $36 \%$ & - & - & - \\
\hline & Fluoxetine & - & $23-62 \%$ & - & - \\
\hline Antiepileptic & Carbamazepine & $0 \%$ & $0-10 \%$ & $0-11 \%$ & $0 \%$ \\
\hline Antihypertension & Diltiazem & $0 \%$ & $13 \%$ & - & - \\
\hline Antiseptic & Triclosan & $28 \%$ & $55-99 \%$ & - & - \\
\hline \multirow{3}{*}{$\beta$-blocker } & Atenolol & $9 \%$ & $14 \%$ & $40 \%$ & - \\
\hline & Metoprolol & & $7 \%$ & - & - \\
\hline & Propranolol & $0 \%$ & $1 \%$ & - & - \\
\hline Lipid Regulator & Gemfibrozil & - & $23-76 \%$ & - & - \\
\hline CEC Metabolite & Cotinine & - & $54 \%$ & - & - \\
\hline Pesticide & Atrazine & - & - & $8 \%$ & - \\
\hline Psycho-stimulant & Caffeine & $0 \%$ & $95-99 \%$ & - & $99 \%$ \\
\hline
\end{tabular}


Table 1. Cont.

\begin{tabular}{ccc}
\hline (b) Whole trains in pilot- and full-scale WWTPs & & \\
\hline Class & Compound & Removal [75,78, 115,116,122] \\
\hline Analgesic & Acetaminophen & $98-99 \%$ \\
& Diclofenac & $78 \%-95 \%$ \\
& Ibuprofen & $43-88 \%$ \\
Antibiotic & Naproxen & $63 \%$ \\
& Sulfamethoxazole & $58 \%$ \\
Antidepressant & Trimethoprim & $41-55 \%$ \\
& Diazepam & $72 \%$ \\
Antiepileptic & Fluoxetine & $0-42 \%$ \\
Antihypertension & Carbamazepine & $22 \%$ \\
Antiseptic & Diltiazem & $69-88 \%$ \\
B-blocker & Triclosan & $41-50 \%$ \\
& Atenolol & $61 \%$ \\
Lipid Regulator & Metoprolol & $0 \%$ \\
CEC Metabolite & Propranolol & $52-88 \%$ \\
Pesticide & Gemfibrozil & $78 \%$ \\
Psycho-stimulant & Cotinine & $68 \%$ \\
& Atrazine & $44-86 \%$ \\
\hline
\end{tabular}

\subsection{Adverse Effects from CECs}

CECs are making their way to surface water and therefore exert potentially adverse effects on aquatic ecosystems. Although concentrations in the $\mathrm{ng} / \mathrm{L}$ may appear to be relatively low, environmental exposure cannot be ignored. For example, in a wetland receiving secondary-treated wastewater effluents, the accumulation of insecticide dieldrin was observed in Mosquitofish (Gambusia affinis) at $8.3 \mathrm{ng} / \mathrm{g}$ of the whole fish body [123]. Brozinski et al. (2013) detected diclofenac (6-148 $\mu \mathrm{g} / \mathrm{L})$, naproxen $(6-103 \mu \mathrm{g} / \mathrm{L})$, and ibuprofen (15-34 $\mu \mathrm{g} / \mathrm{L}$ ) in the bile of two wild fish bream (Abramis brama) and roach (Rutilus rutilus) living in a lake that receives discharges with CECs from WWTPs [124]. CECs have been found to alter the freshwater macroinvertebrate community structure [125]. For example, the discharge of carbamazepine (1 to $88 \mathrm{ng} / \mathrm{L})$ from WWTP effluents and septic wastewater impacted the abundance of Baetidae in surface water downstream [125], where the Baetidae abundance $(r=0.52, p=0.022)$ and macroinvertebrate richness $(r=0.48$, $p=0.037)$ significantly increased.

Observations of antibiotic resistance of bacteria [30,126-130], intersex occurrence in freshwater fish [31,131-133], and oxidative stress in aquatic organisms [134-137] are major adverse effects from CECs in the water cycle [138]. Many researchers have investigated the effect of the wastewater treatment processes on the prevalence of antibiotic-resistant bacteria in the plants and receiving waters $[126,128,129]$. A number of stream surveys documented the significant prevalence of native bacteria that display resistance to a wide array of antibiotics, including vancomycin [139]. Lateef (2004) examined 25 bacterial strains isolated from a pharmaceutical company's effluent and their resistance to commonly used antibiotics [127]. Around $80 \%$ of the isolates were resistant to amoxicillin, $76 \%$ to nitrofurantoin, $64 \%$ to cotrimoxazole, and $12 \%$ to gentamicin. These strains impact ecosystems, animal husbandry, and humans. WWTPs are important reservoirs of bacteria in which antibiotic-resistant organisms persist and may be released into the environment. As environmental compartments are interconnected, including municipal sewage and surface water, WWTPs may facilitate the spread of antibiotics, antibiotic resistance genes, and antibiotic-resistant bacteria [140]. Zhang et al. (2009) found that the frequency of antibiotic-resistant bacteria to rifampin, chloramphenicol, and amoxicillin/clavulanic acid was greater downstream than upstream in a river receiving a wastewater effluent discharge [140]. Such effluents contribute to the increase in antibiotic resistance in aquatic environments. These reports suggest that the occurrence of antibiotic-resistant bacteria 
is much greater than expected where the uncontrolled release of antibiotics into the environment may prompt an increase in resistance. Excluding the significance of antibiotics themselves in the environment, their occurrence implicates the presence of other CECs and suggests further adverse effects on humans, including increased antibiotic resistance, resulting in the formation of superbugs.

During the last decade, a significant amount of research has helped to clarify the potential risk of exposure to endocrine-disrupting chemicals (EDCs) [131,132,141-145]. Adverse effects on fish populations have been frequently recorded downstream of sources of aquatic contamination. Masculinization of female fish was one of the first recorded effects, when mosquito fish downstream of a pulp and paper mill were found to have male secondary sexual characteristics [146]. The converse effect has been frequently reported as well in freshwaters downstream of wastewater treatment plants, where feminization of male fish and mollusks through estrogen contamination in the effluent has a pronounced effect. Feminization of reproductive ducts in male fish, appearance of oocytes in male gonads, and the characteristic production of the female egg protein vitellin in male fish exposed to wastewater from sewage treatment plants have been recorded [147]. Feminization of fish in English rivers is widespread, attributed to estrogen in sewage effluent [143]. Jobling et al. were the first to document an example of widespread sexual disruption in wild populations of any vertebrate, demonstrating that reproductive and developmental effects do result from exposure to ambient levels of chemicals present in rivers. A 7-year lake experiment was conducted in Northwestern Ontario, Canada [132], for determining the adverse impact of chronic exposure to a complex mixture of compounds containing estrogens and estrogen-mimicking compounds on fish populations. The results showed that chronic exposure of fathead minnows to low concentrations (5-6 ng/L) of 17- $\alpha$-ethynylestradiol led to feminization of males. Impacts on gonadal development as evidenced by intersex in males and altered oogenesis in females, and, ultimately, the near extinction of this species from the lake, demonstrated that what are considered low concentrations of estrogen and estrogen mimicking compounds may have profound developmental effects on wild fish populations. Hinck et al. (2009) found that intersex occurred in 3\% of freshwater fish evaluated in nine river basins in the U.S. [131]. Intersex was most prevalent in largemouth bass (8-91\% per site) and small mouth bass (14-73\% per site). The authors hypothesized that the prevalence of intersex may be related to the season, the age of fish, and the endocrine active compounds in the environment.

A number of studies have focused on the oxidative stress induced by the exposure to environmentally relevant concentrations of CECs. Almedia et al. (2015) evaluated the chronic toxicity of carbamazepine on clams (Ruditapes philippinarum) exposed to $0.03,0.30$, 3.00, and $9.00 \mu \mathrm{g} / \mathrm{L}$ for 28 days [134]. At greater concentrations of 3.00 and $9.00 \mu \mathrm{g} / \mathrm{L}$, a significant decrease in the antioxidant enzymes was observed and led to the impairment of the ability to cope with oxidative stress. Similarly, in galaxiid fish, an acute exposure to $0.17 \mu \mathrm{g} / \mathrm{L}$ of diclofenac for $96 \mathrm{~h}$ resulted in a decrease in catalase activity in the gill tissue [135]. Stancova et al. (2017) evaluated the early stages of oxidative stress in Tench fish exposed to environmentally relevant concentrations $(0.02-60 \mu \mathrm{g} / \mathrm{L})$ of ibuprofen, diclofenac, and carbamazepine [137]. Significant impacts were observed in oxidative stress parameters glutathione reductase, glutathione peroxidase, and glutathione-S-transferase after the exposure. These results suggest that CECs, even at low concentrations ranging from $\mathrm{ng} / \mathrm{L}$ to $\mu \mathrm{g} / \mathrm{L}$, exert potentially adverse effects on aquatic organisms. Therefore, CECs that make their way through WTPs and persist in the drinking water may threaten human health and are most important.

\subsection{Removal Efficacy in WTPs}

A significant amount of work has been focused on treatment through WTPs. Studies have included evaluating the effectiveness of conventional processes that include coagulation, filtration, and disinfection along with advanced processes such as granular activated carbon (GAC), biologically active filters (BAFs), ozonation with and without 
$\mathrm{H}_{2} \mathrm{O}_{2}$, and $\mathrm{UV} / \mathrm{H}_{2} \mathrm{O}_{2}$. A number of studies have been conducted to determine the degree to which individual and combined conventional and advanced water treatment processes are capable of removing CECs.

Coagulation has been reported as ineffective in treating CECs [16,104,148-151]. Westerhoff et al. (2005) evaluated the removal of CECs in coagulation with aluminum sulfate and ferric chloride [151]. Generally, at a pH of 6.8, removals were less than $50 \%$. The exception included a few polycyclic aromatic hydrocarbons (e.g., benzo[k]fluoranthene, and benzo[a]pyrene) and the pesticide dichlorodiphenyl-dichloroethylene (DDE), with $\log \mathrm{K}_{\mathrm{ow}}$ values greater than 5.5 indicating their hydrophobic properties and potential for partitioning during coagulation. Similar trends were observed by Huerta-Fontela et al. (2011), where removals were less than $30 \%$ for hydrophilic compounds $\left(\log \mathrm{K}_{\mathrm{ow}}<3\right.$ ) such as atenolol, propranolol, carbamazepine, and diltiazem [16]. Overall, coagulation is a relatively ineffective process. Similarly, dual media filtration yields poor removals as well. In a pilot plant study, anthracite/sand dual media filters with empty bed contact time (EBCT) of 6 min achieved removals of less than 50\% for the 15 CECs studied [152] (Table 2). Chlorine was found to be an ineffective oxidizing reagent for CECs. Studies examined the removal efficiency of chlorination, with dosages ranging from 1 to $2.6 \mathrm{mg} / \mathrm{L}$ and a contact time of 60 min [152-154]. Limited removals ( $0 \%$ to $62 \%$ ) were observed (Table 2). For example, with a dosage of $1 \mathrm{mg} \mathrm{Cl} / \mathrm{L}$, removals of less than $40 \%$ were reported for the antiseptic triclosan $(36 \%)$, analgesic ibuprofen (3\%), steroid estrone (36\%), lipid regulator clofibric acid (5\%), and X-ray contrast agent iopromide ( $\%$ ) [154]. Only steroids including estriol $(53 \%)$, estradiol (58\%), and ethynlestradiol (41\%) were removed by greater than $40 \%$. Overall, conventional treatment processes including coagulation, filtration, and chlorination showed limited CEC removal.

Table 2. CEC removal in conventional treatment processes.

\begin{tabular}{|c|c|c|c|}
\hline \multirow{2}{*}{ Compounds } & \multirow{2}{*}{$\begin{array}{c}\text { Coagulation } \\
\text { [148-152] }\end{array}$} & \multirow{2}{*}{$\begin{array}{c}\text { Filtration } \\
{[148,152]}\end{array}$} & \multirow{2}{*}{$\begin{array}{c}\text { Chlorination [148,152-154] } \\
\text { Contact Time: } 60 \mathrm{~min} \\
\end{array}$} \\
\hline & & & \\
\hline \multicolumn{4}{|l|}{ Analgesics } \\
\hline Acetaminophen & - & $0 \%$ & $59-62 \%$ \\
\hline Diclofenac & $<10 \%$ & - & - \\
\hline Hydrocodone & $24 \%$ & - & - \\
\hline Ibuprofen & $<10 \%$ & $0-12 \%$ & $3-22 \%$ \\
\hline Naproxen & $<5 \%$ & & $23 \%$ \\
\hline \multicolumn{4}{|l|}{ Antibiotic } \\
\hline Erythromycin & - & $0-7 \%$ & $8 \%$ \\
\hline Sulfamethazine & - & $12 \%$ & $0 \%$ \\
\hline Sulfamethoxazole & - & $0-21 \%$ & $0 \%$ \\
\hline Trimethoprim & - & $0-43 \%$ & - \\
\hline \multicolumn{4}{|l|}{ Antidepressant } \\
\hline Fluoxetine & $<15 \%$ & - & - \\
\hline \multicolumn{4}{|l|}{ Antiepileptic } \\
\hline Carbamazepine & $<5 \%$ & $0-7 \%$ & $0-14 \%$ \\
\hline \multicolumn{4}{|l|}{ Antiseptic } \\
\hline Triclosan & - & - & $36 \%$ \\
\hline \multicolumn{4}{|l|}{ Beta-Blocker } \\
\hline Atenolol & - & $0-22 \%$ & $19 \%$ \\
\hline Metoprolol & - & - & $0 \%$ \\
\hline \multicolumn{4}{|l|}{ Fire Retardant } \\
\hline TCEP & $0 \%$ & $0 \%$ & $0 \%$ \\
\hline \multicolumn{4}{|l|}{ Lipid Regulator } \\
\hline Atorvastatin & $<10 \%$ & - & - \\
\hline Clofibric Acid & - & - & $5 \%$ \\
\hline Gemfibrozil & $<5 \%$ & $2-14 \%$ & $22 \%$ \\
\hline
\end{tabular}


Table 2. Cont.

\begin{tabular}{|c|c|c|c|}
\hline \multirow{2}{*}{ Compounds } & \multirow{2}{*}{$\begin{array}{c}\text { Coagulation } \\
\text { [148-152] }\end{array}$} & \multirow{2}{*}{$\begin{array}{c}\text { Filtration } \\
{[148,152]}\end{array}$} & \multirow{2}{*}{$\begin{array}{c}\text { Chlorination }[148,152-154] \\
\text { Contact Time: } 60 \mathrm{~min}\end{array}$} \\
\hline & & & \\
\hline \multicolumn{4}{|l|}{ Metabolite } \\
\hline Cotinine & - & $0 \%$ & $0 \%$ \\
\hline \multicolumn{4}{|l|}{ Pesticide } \\
\hline Atrazine & $0-10 \%$ & $0 \%$ & $0 \%$ \\
\hline DEET & $0 \%$ & $0-14 \%$ & $0 \%$ \\
\hline \multicolumn{4}{|l|}{ Plasticizer } \\
\hline BPA & $<5 \%$ & & $11 \%$ \\
\hline \multicolumn{4}{|l|}{ Steroid } \\
\hline Estradiol & $2 \%$ & $0 \%$ & $58 \%$ \\
\hline Estriol & - & - & $53 \%$ \\
\hline Estrone & $5 \%$ & - & $36 \%$ \\
\hline Ethynylestradiol & $0 \%$ & - & $41 \%$ \\
\hline \multicolumn{4}{|l|}{ Stimulants } \\
\hline Caffeine & $0 \%$ & $0-44 \%$ & $9-59 \%$ \\
\hline \multicolumn{4}{|l|}{ Surfactant } \\
\hline PFOA & $<12.5 \%$ & $0 \%$ & $10 \%$ \\
\hline PFOS & $<12.5 \%$ & $0 \%$ & $0 \%$ \\
\hline \multicolumn{4}{|l|}{$\begin{array}{c}\text { X-Ray Contrast } \\
\text { Media }\end{array}$} \\
\hline Iopromide & - & $0-27 \%$ & $0 \%$ \\
\hline
\end{tabular}

Virgin GAC was highly effective in treating CECs, with removals generally greater than $90 \%$; the exception was DEET, with a removal of approximately $70 \%$ [52]. However, consideration of breakthrough and regeneration frequency needs to be addressed for GAC $[155,156]$. PFOA and PFOS were removed to below their detection limits in a fullscale GAC contactor with an EBCT of $13 \mathrm{~min}$ [148]. After a bed volume of approximately 65,000 , the removal dropped to less than $50 \%$ and $75 \%$ for PFOA and PFOS, respectively. CECs were removed by greater than $90 \%$ in a full-scale GAC with an EBCT of $7.6 \mathrm{~min}$. However, 20\% breakthrough was observed after bed volumes ranging from 30,700 for sulfamethoxazole to 78,600 for carbamazepine [155]. $\mathrm{K}_{\mathrm{oc}}$ is an important indicator of the GAC's effectiveness; less than $570 \mathrm{mg} / \mathrm{g} C$ resulted in removals of less than $40 \%$ [52] (Table 3). For TCEP $\left(K_{\mathrm{oc}}=71 \mathrm{mg} / \mathrm{g} C\right)$ and DEET $\left(K_{\mathrm{oc}}=300 \mathrm{mg} / \mathrm{g} \mathrm{C}\right)$, removals were less than $43.2 \%$ in a full-scale GAC filter with an EBCT ranging from 1.5 to $3 \mathrm{~min}$ [104]. Amitrol, nonylphenol, and bisphenol-A, with $\log \mathrm{K}_{\mathrm{ow}}$ of $-0.86,5.76$, and 3.32, respectively, were studied, and while the latter two were effectively adsorbed, amitrol was not [157]. 
Table 3. CEC removals in advanced treatment processes.

\begin{tabular}{|c|c|c|c|c|c|c|c|c|c|c|c|c|}
\hline \multirow{3}{*}{ Compounds } & \multirow{3}{*}{$\begin{array}{c}\text { GAC [148, } \\
\begin{array}{c}\text { 152,155,158] } \\
\text { Virgin }\end{array} \\
6-7.6\end{array}$} & \multirow{3}{*}{$\begin{array}{c}\text { GAC } \\
{[104,155]} \\
\text { w/o Reg. } \\
\text { EBCT } \\
3-15\end{array}$} & \multirow{3}{*}{$\begin{array}{c}\text { GAC } \\
\text { BAF [158] } \\
\begin{array}{l}\text { min) } \\
\text { 9-18 }\end{array}\end{array}$} & \multirow{3}{*}{\begin{tabular}{|c|}
$\begin{array}{c}\text { DM or } \\
\text { Sand BAF } \\
{[156,157]}\end{array}$ \\
$5-15.8$ \\
\end{tabular}} & \multicolumn{3}{|c|}{ Ozone w/o $\mathrm{H}_{2} \mathrm{O}_{2}[152,159]$} & \multirow{2}{*}{\multicolumn{2}{|c|}{$\begin{array}{c}\text { Ozone w/ } \mathrm{H}_{2} \mathrm{O}_{2} \\
{[49]} \\
\mathrm{H}_{2} \mathrm{O}_{2} / \mathrm{TOC} *\end{array}$}} & \multicolumn{2}{|c|}{ UV w/o $\mathbf{H}_{2} \mathrm{O}_{2}[51,148]$} & \multirow{3}{*}{$\begin{array}{c}\mathrm{UV} \mathrm{w} / \mathrm{H}_{2} \mathrm{O}_{2}[51] \\
372 \mathrm{~mJ} / \mathrm{cm}^{2}-5 \mathrm{mg} / \mathrm{L}\end{array}$} \\
\hline & & & & & \multicolumn{3}{|c|}{$\mathrm{O}_{3} / \mathrm{TOC}^{*}$} & & & \multirow{2}{*}{$40 \mathrm{~mJ} / \mathrm{cm}^{2}$} & \multirow{2}{*}{$439 \mathrm{~mJ} / \mathrm{cm}^{2}$} & \\
\hline & & & & & $0.2-0.3$ & 0.6 & 1.0 & 0.2 & 0.7 & & & \\
\hline Analgesics & & & & & & & & & & & & \\
\hline Acetaminophen & $90 \%$ & $25-99 \%$ & - & $59-79 \%$ & $>99 \%$ & - & - & $88 \%$ & - & $20-50 \%$ & $>80 \%$ & $>80 \%$ \\
\hline Diclofenac & - & $69 \%$ & $98-99 \%$ & $21-28 \%$ & $20-95 \%$ & $95-99 \%$ & $>99 \%$ & - & $>99 \%$ & $50-80 \%$ & $>80 \%$ & $>80 \%$ \\
\hline Ibuprofen & $90 \%$ & $16 \%$ & - & $70-95 \%$ & $10-72 \%$ & $30-99 \%$ & $90-95 \%$ & $80 \%$ & $83 \%$ & $<20 \%$ & $20-50 \%$ & $>80 \%$ \\
\hline Naproxen & - & $6 \%$ & $90-98 \%$ & $50-90 \%$ & $20-99 \%$ & $>99 \%$ & $>99 \%$ & - & $>99 \%$ & $<20 \%$ & $>80 \%$ & $>80 \%$ \\
\hline Antibiotic & & & & & & & & & & & & \\
\hline Erythromycin & $90 \%$ & $8 \%$ & $85-98 \%$ & $15-27 \%$ & $91 \%$ & $93 \%$ & - & - & - & $<20 \%$ & $50-80 \%$ & $50-80 \%$ \\
\hline Sulfamethoxazole & $90 \%$ & $84 \%$ & $96-98 \%$ & $2.4-4.1 \%$ & $25-99 \%$ & $>95 \%$ & $>99 \%$ & $99 \%$ & $98 \%$ & $50-80 \%$ & $>80 \%$ & $>80 \%$ \\
\hline Trimethoprim & $90 \%$ & $64 \%$ & $96-98 \%$ & $83-92 \%$ & $50-99 \%$ & $93-99 \%$ & $>99 \%$ & $95 \%$ & $>99 \%$ & $<20 \%$ & $20-50 \%$ & $>80 \%$ \\
\hline Antidepressant & & & & & & & & & & & & \\
\hline Diazepam & - & - & - & - & $20-30 \%$ & $65-75 \%$ & $90-99 \%$ & - & $>90 \%$ & $<20 \%$ & $<20 \%$ & $50-80 \%$ \\
\hline Antiepileptic & & & & & & & & & & & & \\
\hline Carbamazepine & $90 \%$ & $16 \%$ & $90-88 \%$ & $0.5-1.6 \%$ & $50-99 \%$ & $91-99 \%$ & $>99 \%$ & $87-99 \%$ & $>99 \%$ & $<20 \%$ & $20-50 \%$ & $>80 \%$ \\
\hline Dilantin & $90 \%$ & $8 \%$ & - & - & $0-55 \%$ & $50-85 \%$ & $90-95 \%$ & - & - & $<20 \%$ & $50-80 \%$ & $>80 \%$ \\
\hline Antiseptic & & & & & & & & & & & & \\
\hline Triclosan & - & $0 \%$ & - & $90 \%$ & $45-95 \%$ & $>95 \%$ & $>95 \%$ & - & $>99 \%$ & $50-80 \%$ & $>80 \%$ & $>80 \%$ \\
\hline Beta-Blocker & & & & & & & & & & & & \\
\hline Atenolol & $90 \%$ & $62 \%$ & $40-70 \%$ & - & $20-50 \%$ & $65-99 \%$ & $>99 \%$ & $85 \%$ & $99 \%$ & - & - & - \\
\hline Metoprolol & - & $40 \%$ & $50-80 \%$ & - & - & - & - & - & - & - & - & - \\
\hline Fire Retardant & & & & & & & & & & & & \\
\hline TCEP & $90 \%$ & $0 \%$ & - & - & $0-10 \%$ & $0-10 \%$ & $10 \%$ & $17-21 \%$ & $13 \%$ & $<20 \%$ & $<20 \%$ & $<20 \%$ \\
\hline Lipid Regulator & & & & & & & & & & & & \\
\hline Clofibric Acid & - & - & - & $35-52 \%$ & - & - & - & - & - & - & - & - \\
\hline Gemfibrozil & $90 \%$ & $8 \%$ & $80-97 \%$ & $70-94 \%$ & $30-91 \%$ & $82-99 \%$ & $>99 \%$ & & $>99 \%$ & $<20 \%$ & $20-50 \%$ & $>80 \%$ \\
\hline Metabolite & & & & & & & & & & & & \\
\hline Cotinine & $90 \%$ & - & - & $23-39 \%$ & $0 \%$ & $32 \%$ & - & $13 \%$ & - & - & - & - \\
\hline
\end{tabular}


Table 3. Cont.

\begin{tabular}{|c|c|c|c|c|c|c|c|c|c|c|c|c|}
\hline \multirow{3}{*}{ Compounds } & \multirow{3}{*}{$\begin{array}{c}\text { GAC [148, } \\
\begin{array}{c}\text { 152,155,158] } \\
\text { Virgin }\end{array} \\
6-7.6\end{array}$} & \multirow{3}{*}{$\begin{array}{c}\text { GAC } \\
\text { [104,155] } \\
\text { w/o Reg. } \\
\text { EBCT } \\
3-15 \\
\end{array}$} & \multirow{3}{*}{$\begin{array}{c}\text { GAC } \\
\text { BAF [158] } \\
\begin{array}{l}\min ) \\
\mathbf{9 - 1 8}\end{array}\end{array}$} & \multirow{3}{*}{$\begin{array}{c}\begin{array}{c}\text { DM or } \\
\text { Sand BAF } \\
{[156,157]}\end{array} \\
\mathbf{5 - 1 5 . 8}\end{array}$} & \multirow{2}{*}{\multicolumn{3}{|c|}{$\begin{array}{c}\text { Ozone w/o } \mathrm{H}_{2} \mathrm{O}_{2}[152,159] \\
\mathrm{O}_{3} / \mathrm{TOC}^{*}\end{array}$}} & \multirow{2}{*}{\multicolumn{2}{|c|}{$\begin{array}{c}\text { Ozone w/ } \mathbf{H}_{2} \mathbf{O}_{2} \\
{[49]} \\
\mathbf{H}_{2} \mathbf{O}_{2} / \text { TOC }^{*}\end{array}$}} & \multicolumn{2}{|c|}{ UV w/o $\mathrm{H}_{2} \mathrm{O}_{2}[51,148]$} & \multirow{3}{*}{$\begin{array}{c}\mathrm{UV} \text { w/ } / \mathrm{H}_{2} \mathrm{O}_{2}[51] \\
372 \mathrm{~mJ} / \mathrm{cm}^{2}-5 \mathrm{mg} / \mathrm{I}\end{array}$} \\
\hline & & & & & & & & & & \multirow{2}{*}{$40 \mathrm{~mJ} / \mathrm{cm}^{2}$} & \multirow{2}{*}{$439 \mathrm{~mJ} / \mathrm{cm}^{2}$} & \\
\hline & & & & & $0.2-0.3$ & 0.6 & 1.0 & 0.2 & 0.7 & & & \\
\hline Pesticide & & & & & & & & & & & & \\
\hline Atrazine & $90 \%$ & $3 \%$ & - & $0.2-3 \%$ & $5-25 \%$ & $0-50 \%$ & $60-99 \%$ & $75 \%$ & $69 \%$ & $<20 \%$ & $50-80 \%$ & $50-80 \%$ \\
\hline DEET & $70-90 \%$ & $43-63 \%$ & - & $15-70 \%$ & $20-69 \%$ & $31-75 \%$ & $85-95 \%$ & $99 \%$ & $90 \%$ & $<20 \%$ & $<20 \%$ & $50-80 \%$ \\
\hline \multicolumn{13}{|l|}{ Plasticizer } \\
\hline BPA & - & - & - & - & - & - & - & - & $>78 \%$ & - & - & - \\
\hline \multicolumn{13}{|l|}{ Steroid } \\
\hline Estradiol & $90 \%$ & - & - & - & $>99 \%$ & $98 \%$ & - & $97 \%$ & $>83 \%$ & $<20 \%$ & $>80 \%$ & $>80 \%$ \\
\hline Estriol & - & $0 \%$ & - & - & - & - & - & - & - & $<20 \%$ & $>80 \%$ & $>80 \%$ \\
\hline Estrone & - & - & - & - & $65-99 \%$ & $>99 \%$ & $>99 \%$ & - & $>98 \%$ & $<20 \%$ & $>80 \%$ & $>80 \%$ \\
\hline Ethynylestradiol & - & - & - & $12-22 \%$ & - & - & - & - & - & $<20 \%$ & $>80 \%$ & $>80 \%$ \\
\hline Progesterone & - & - & - & - & - & - & - & - & - & $<20 \%$ & $20-50 \%$ & $>80 \%$ \\
\hline \multicolumn{13}{|l|}{ Stimulants } \\
\hline Caffeine & $90 \%$ & $16 \%$ & $10-50 \%$ & $67-80 \%$ & $20-55 \%$ & 39-99\% & $>99 \%$ & $99 \%$ & $>74 \%$ & $<20 \%$ & $<20 \%$ & $50-80 \%$ \\
\hline \multicolumn{13}{|l|}{ Surfactants } \\
\hline PFOA & $64-90 \%$ & - & - & - & - & - & - & - & - & $<20 \%$ & - & - \\
\hline PFOS & $81-90 \%$ & - & - & - & - & - & - & - & - & $<20 \%$ & - & - \\
\hline \multicolumn{13}{|l|}{$\begin{array}{l}\text { X-ray Contrast } \\
\text { Media }\end{array}$} \\
\hline
\end{tabular}


Biologically active filters (BAF) are gaining more attention in treating CECs. Recently, a number of studies have been conducted using BAFs to treat CECs in drinking water [160-165]. BAF efficiency was observed to be a function of EBCT [160-162]. For example, in a bench-scale study with an anthracite/sand BAF as the EBCT increased from 5 to $14 \mathrm{~min}$, the removal of the pesticide DEET improved from less than $50 \%$ to as high as $70 \%$, while ibuprofen removal increased from $70 \%$ to greater than $90 \%$. Zearley and Summers (2012) observed improvements for acetaminophen, naproxen, caffeine, and gemfibrozil when the EBCT doubled from 7.9 to $15.8 \mathrm{~min}$ [161]. Pre-ozonation has been found to increase the biodegradable fraction of the natural organic matter (NOM) [163]. Lee et al. (2012) examined CEC removal as a function of pre-ozonation dosage in anthracite BAF [163]. Nine out of 15 CECs were removed at greater than $75 \%$ with an ozone dosage of $4 \mathrm{mg} / \mathrm{L}$, while only three compounds were removed to the same extent when the dosage decreased to $2 \mathrm{mg} / \mathrm{L}$. Zhang et al. (2017) converted existing filters in WTPs into BAFs and evaluated the CEC removals as a function of media, EBCT, and pre-ozonation [165]. At an 18-min EBCT, GAC BAFs without ozonation removed CECs studied at greater than $80 \%$; the exceptions included TCEP and iopromide, which were removed at $76 \%$ and $59 \%$, respectively. Reducing the EBCT to 10 min resulted in less than half of the CECs being removed to the same extent. Dual-media BAFs showed limited removals, with only four compounds removed at greater than $80 \%$ at either EBCT.

Ozonation degrades the contaminants by direct oxidation and hydroxyl radical $(\mathrm{OH} \bullet)$. Generally, increased removals were observed with increasing ozone dosage. Wert et al. (2009) investigated three ozone dosages, $0.2,0.6$, and $1.0 \mathrm{mg} \mathrm{O}_{3} / \mathrm{mg}$ total organic carbon (TOC), in a pilot plant study where tertiary-treated effluents from three WWTPs with TOC ranging from 6.6 to $10.3 \mathrm{mg} / \mathrm{L}$ were tested [159]. Removals of 23 CECs through ozonation were evaluated. The most recalcitrant compounds were atrazine, iopromide, tris(1-chloro-2-propyl) phosphate (TCPP), and TCEP, with removals less than $60 \%$ even at the greatest ozone dosage $9.27 \pm 2.31 \mathrm{mg} / \mathrm{L}$. Thirteen compounds were removed at greater than $80 \%$, with two of the ozone dosages of $5.87 \pm 1.63$ and $9.27 \pm 2.31 \mathrm{mg} \mathrm{O}_{3} / \mathrm{L}$, while all 23 compounds were removed at less than $80 \%$ for the lowest ozone dosage of $2.27 \pm 0.49 \mathrm{mg}$ $\mathrm{O}_{3} / \mathrm{L}$. As a selective oxidant, ozone rate constants $\left(\mathrm{k}_{\mathrm{O} 3}\right)$ vary between less than 1 and $3 \times 10^{6} \mathrm{M}^{-1} \mathrm{~s}^{-1}$. Compounds with $\mathrm{k}_{\mathrm{O} 3}$ greater than $10^{5} \mathrm{M}^{-1} \mathrm{~s}^{-1}$ are highly reactive

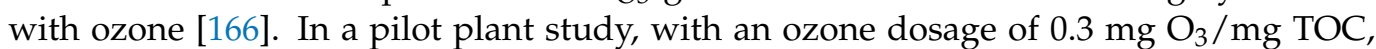
acetaminophen $\left(\mathrm{k}_{\mathrm{O} 3}=2.1 \times 10^{5} \mathrm{M}^{-1} \mathrm{~s}^{-1}\right)$, sulfamethoxazole $\left(\mathrm{k}_{\mathrm{O} 3}=5.5 \times 10^{5} \mathrm{M}^{-1} \mathrm{~s}^{-1}\right)$, trimethoprim $\left(\mathrm{k}_{\mathrm{O} 3}=2.7 \times 10^{5} \mathrm{M}^{-1} \mathrm{~s}^{-1}\right)$, carbamazepine $\left(\mathrm{k}_{\mathrm{O} 3}=3 \times 10^{5} \mathrm{M}^{-1} \mathrm{~s}^{-1}\right)$, and $17 \beta$ estradiol $\left(\mathrm{k}_{\mathrm{O} 3}=10^{6} \mathrm{M}^{-1} \mathrm{~s}^{-1}\right)$ were removed at greater than $90 \%$, while average removals were less than $60 \%$ for compounds with $\mathrm{k}_{\mathrm{O} 3}$ less than $10 \mathrm{M}^{-1} \mathrm{~s}^{-1}$, such as atrazine, DEET, ibuprofen, TCEP, and iopromide [152].

Compared to ozone, $\mathrm{OH} \bullet$ rate constants differ by less than one order of magnitude, with less selectivity than $\mathrm{O}_{3}[151,159,167]$. Gerrity et al. (2011) evaluated the removals in ozonation with the addition of $\mathrm{H}_{2} \mathrm{O}_{2}$ at a mass ratio of 0.7 [49]. Removals were considerably improved, with almost all the compounds removed at greater than $80 \%$; the exceptions were atrazine, TCEP, and TCPP. The recalcitrant compounds for ozonation included pesticide atrazine, fire retardants TCEP and TCPP, and the X-ray contrast agent iopromide.

Removal efficiency in advanced oxidation process $\mathrm{UV} / \mathrm{H}_{2} \mathrm{O}_{2}$ is dependent on the $\mathrm{UV}$ intensity and $\mathrm{H}_{2} \mathrm{O}_{2}$ addition. At the typical UV dosage used in disinfection of $40 \mathrm{~mJ} / \mathrm{cm}^{2}$ [168], CECs removals were poor $(<20 \%$ for target compounds). Increasing the dosage by an order of magnitude resulted in increased removal of the majority of target compounds, with only four compounds (i.e., TCEP, DEET, metolachlor, and caffeine) removed at less than $20 \%$. UV with $\mathrm{H}_{2} \mathrm{O}_{2}$ provides improved performance as UV activates $\mathrm{H}_{2} \mathrm{O}_{2}$ and leads to the formation of the $\mathrm{OH} \bullet$ radical. Rosario-Ortiz et al. (2010) investigated the removal of six CECs (atenolol, carbamazepine, dilantin, meprobamate, primidone, and trimethoprim) as a function of UV intensity $\left(300,500\right.$, and $700 \mathrm{~mJ} / \mathrm{cm}^{2}$ ) with a range of $\mathrm{H}_{2} \mathrm{O}_{2}$ dosages ( 0 to $20 \mathrm{mg} / \mathrm{L}$ ) [169]. At the lowest $\mathrm{UV}$ intensity, removals were generally less than $50 \%$. With UV intensity greater or equal to $500 \mathrm{~mJ} / \mathrm{cm}^{2}$ and $\mathrm{H}_{2} \mathrm{O}_{2}$ 
dosages between 15 and $20 \mathrm{mg} / \mathrm{L}$, removals of as great as 90\% were observed for atenolol, carbamazepine, and trimethoprim. Generally, UV oxidation alone with an intensity of $500 \mathrm{~mJ} / \mathrm{cm}^{2}$ or greater is a promising process for treating CECs [169]. With intensity of less than $500 \mathrm{~mJ} / \mathrm{cm}^{2}$, the addition of $\mathrm{H}_{2} \mathrm{O}_{2}$ is required.

In a pilot plant study, 12 treatment trains were investigated to understand the optimal combination of unit processes for treating 15 indicator CECs. Unit processes included dissolved air flotation (DAF), pre- and intermediate-ozonation with and without $\mathrm{H}_{2} \mathrm{O}_{2}$, intermediate chlorination, dual-media filtration, GAC, and $\mathrm{UV} / \mathrm{H}_{2} \mathrm{O}_{2}$ [152]. The most effective trains involved 1. DAF followed by intermediate ozonation, dual-media filtration, and virgin GAC; 2 . pre-ozonation followed by DAF, dual-media filtration, and virgin GAC; and 3. DAF (with either pre- or intermediate oxidation) followed by dual-media filtration and $\mathrm{UV} / \mathrm{H}_{2} \mathrm{O}_{2}$, where 13 to 15 of the indicator compounds were removed at greater than 90\%. Pre-ozonation followed by DAF showed reduced CEC removal compared to DAF, followed by intermediate ozonation, demonstrating the importance of removing NOM before this process. TCEP and cotinine were generally observed to be the most recalcitrant indicator compounds, with removals of less than $35 \%$ and $80 \%$, respectively, in most of the treatment trains.

In summary, conventional treatment processes provide limited removals. Studies with advanced treatment processes report removals of greater than $80 \%$ for virgin GAC, GAC BAFs, ozonation with a dosage at greater than $0.6 \mathrm{mg} \mathrm{O}_{3} / \mathrm{mg}$ TOC, ozonation with $\mathrm{H}_{2} \mathrm{O}_{2}$, UV oxidation without $\mathrm{H}_{2} \mathrm{O}_{2}$ at an intensity greater than $400 \mathrm{~mJ} / \mathrm{cm}^{2}$, or UV with $\mathrm{H}_{2} \mathrm{O}_{2}$ at an intensity less than $400 \mathrm{~mJ} / \mathrm{cm}^{2}$. Treatment trains that achieved the greatest removals included DAF in combination with pre- or intermediate ozonation, followed by dual-media filtration and virgin GAC, with most of the compounds removed at greater than $90 \%$. However, fire retardant TCEP $(<20 \%)$, metabolite cotinine $(<40 \%)$, pesticides atrazine (generally $<80 \%$ ), DEET (generally $<80 \%$ ), metolachlor $(<80 \%)$, and X-ray contrast media iopromide $(<80 \%)$ are still some of the more recalcitrant compounds. Therefore, these CECs are key as the indicator compounds.

\subsection{Potential Risks to Human Health}

As some CECs are recalcitrant through the treatment processes in WTPs, their possible occurrence in drinking water systems is of great concern because of the potential risks to human health. To assess the potential human health concern, Schriks et al. (2010) compared the maximum CEC concentrations observed in a freshwater environment (i.e., surface water, groundwater, or drinking water) to the guideline values obtained from either statutory guidelines or derived from toxicological data relevant to human health reported in the literature [34]. Although all maximum CEC concentrations in the freshwater were less than the guideline values, relatively high potential human health concerns were noted for carbamazepine, 1,4-dioxane, and perfluorooctanesulfonic acid as their freshwater concentrations were at least $20 \%$ of the allowed guideline values. The impact of longterm chronic exposure and the synergistic effects of low concentrations of CEC mixtures on human health and potentially sensitive sub-populations remain currently unknown. Murray et al. (2010) calculated a consumption rate posing health risk (CRPHR) for each investigated CEC based on the occurrence in freshwater and the acceptable daily intake (ADI) that considers the uncertainty between effects on animal and human subject [33]. With the CRPHR, $17 \alpha$-ethinylestradiol, carbamazepine, and $17 \beta$-estradiol were found to pose the most potential risk to human health. Similar estimation methods were applied in a number of studies $[170,171]$, though the exposure response to humans was not directly evaluated; rather, quantitative potential risk was calculated [172].

The U.S. EPA established drinking water health advisories for both PFOA and POFS in 2016 [36,37]. Human epidemiology studies have reported an association between PFOA exposure and a series of adverse effects (e.g., high cholesterol, thyroid disorders, pregnancyinduced hypertension, preeclampsia, and testicular and kidney cancer) [36], while exposure to PFOS has been reported to be associated with high cholesterol, thyroid disease, immune 
suppression, reduced fertility, and fecundity [37]. With the potential adverse effects on human health, the EPA has issued a lifetime drinking water health advisory of $0.07 \mu \mathrm{g} / \mathrm{L}$ for both PFOA and PFOS.

\section{Properties of CEC Classes}

Studying the structure of CECs by class is useful in addressing treatment efficacy. A number of CECs are frequently detected in the water cycle. To better understand persistence, degradability, removals, and also to help reduce the number of compounds with similar properties, the physical and chemical properties of groups of CECs routinely found in systems were reviewed. Classes include those that are frequently studied in WWTP, surface water, and drinking water, such as analgesics, antibiotics, antidepressants, antiepileptic, lipid regulators, CEC metabolites, pesticides, and, psycho-stimulants, those that are persistent in surface water and source water, such as $\beta$-blockers and steroids, and those that are recalcitrant during treatment processes, such as fire retardants and X-ray contrast agents.

\subsection{Analgesics}

The great occurrence of analgesics is reported in wastewater, surface water, as well as in drinking water (Figures S1, S15 and S23). Compounds with large $K_{o w}$ values $\left(>10^{3}\right)$ may be considered relatively hydrophobic, with greater soil/sediment adsorption coefficients and lower solubilities in contrast to compounds with low $\mathrm{K}_{\mathrm{ow}}$ values $(<10)$ that are very hydrophilic [173,174]. Solubility affects the fate and transport of organic chemicals in the environment. Highly soluble compounds are easily and quickly distributed in the hydrologic cycle and tend to be more readily biodegradable by microorganisms in wastewater treatment plants and surface water. Among the frequently studied analgesics, ibuprofen, ketoprofen, naproxen, and diclofenac have similar structural features (aromatic rings and carboxylic acid). They exhibit similar $\mathrm{K}_{\mathrm{ow}}$ and $\mathrm{pKa}$ values (Table S8) [35,175]. With large $\mathrm{K}_{\mathrm{ow}}$ values and limited solubilities, biological treatment may not be the most effective treatment for these analgesics. Unlike the above analgesics, acetaminophen has a relatively low $\mathrm{K}_{\mathrm{ow}}$ value $\left(10^{0.46}\right)$, suggesting greater biodegradability.

Compounds with larger $\mathrm{K}_{\mathrm{oc}}$ are more likely to be removed by adsorption. Acetaminophen has relatively greater $\mathrm{K}_{\mathrm{oc}}\left(170-1300 \mathrm{~mL} \cdot \mathrm{g} \mathrm{C}^{-1}\right)$ than ibuprofen $\left(18-155 \mathrm{~mL} \cdot \mathrm{g} \mathrm{C}^{-1}\right)[176,177]$, suggesting that GAC may be effective in removing acetaminophen. Furthermore, acetaminophen has an aromatic ring with a phenolic moiety, suggesting that $\mathrm{O}_{3}$ is relatively effective $[151,159]$. Ibuprofen, with a carboxylic group on its aromatic ring, is an electron-withdrawing functional group that reduces the reactivity of the aromatic ring with ozone $[151,178]$. The ozone rate constant $\left(\mathrm{k}_{\mathrm{O} 3}\right)$ for ibuprofen is $9.6 \mathrm{M}^{-1} \mathrm{~s}^{-1}$, indicating a relatively slow reaction with ozone. In contrast, acetaminophen with a greater rate constant $\left(2.70 \times 10^{5} \mathrm{M}^{-1} \mathrm{~s}^{-1}\right)$ would achieve improved removal through ozonation. With their varying degree of reactivity with ozone and different $\log \mathrm{K}_{\mathrm{ow}}$, acetaminophen and ibuprofen are selected to represent the group of analgesics (Table S8).

\subsection{Antibiotics}

Sufamethoxazole and trimethoprim are the most frequently reported antibiotics in wastewater, surface water, and drinking water (Figures S1, S15 and S23), while erythromycin is observed to be persistent in surface water (Figure S17). From $\mathrm{K}_{\mathrm{ow}}$ values, erythromycin $\left(10^{3.06}\right)$ tends to be more hydrophobic, while sulfamethoxazole $\left(10^{0.89}\right)$ and trimethoprim $\left(10^{0.91}\right.$ ) are relatively hydrophilic (Table S9). With low solubility at $1.44 \mathrm{mg} / \mathrm{L}$, erythromycin may be more difficult to biodegrade than the other two antibiotics. Erythromycin, with $\mathrm{K}_{\mathrm{oc}}$ of $570 \mathrm{~mL} \cdot \mathrm{g} \mathrm{C}^{-1}$, may be more efficiently removed by GAC than sulfamethoxazole $\left(\mathrm{K}_{\mathrm{oc}}=72 \mathrm{~mL} \cdot \mathrm{g} \mathrm{C}^{-1}\right)$ and trimethoprim $\left(\mathrm{K}_{\mathrm{oc}}=75 \mathrm{~mL} \cdot \mathrm{g} \mathrm{C}^{-1}\right)$ [179]. In addition, the ozonation rate constants for sulfamethoxazole and trimethoprim (Table S9) demonstrate the viability of ozonation. Structures with electron donors are amenable to ozonation [178]. Highly reactive compounds include activated aromatic structures (amine 
functionalities) $[151,166]$. The three selected antibiotics have either a primary, secondary, or tertiary amine, suggesting possible locations for ozone to react.

\subsection{Antidepressants}

Diazepam and fluoxetine are the most reported antidepressants, especially in wastewater samples (Figures S5, S18 and S24), while meprobamate is frequently observed in sampled source water and finished drinking water samples (Figure $\mathrm{S} 23$ ). With a low $\mathrm{K}_{\mathrm{ow}}$ value $(\sim 5)$ as well as excellent solubility $(4700 \mathrm{mg} / \mathrm{L})$, meprobamate may possess good biodegradability, while with low solubilities $(\sim 55 \mathrm{mg} / \mathrm{L})$, diazepam and fluoxetine may not be easily biodegraded (Table S10) [35,51]. Moreover, the amide structure (electron-drawing moiety) of diazepam may cause low removal efficiency through ozonation, which is also reflected by the low ozone rate constant $\left(\mathrm{k}_{\mathrm{O} 3}=0.75 \pm 0.15 \mathrm{M}^{-1} \mathrm{~s}^{-1}\right)$ [180]. The secondary amine of fluoxetine and the aliphatic structure of meprobamate suggest their potential reaction with ozonation. With potentially high biodegradability and fast reaction with ozonation, meprobamate is eliminated; diazepam and fluoxetine are selected as the indicator compounds to represent antidepressants.

\subsection{Antiepileptics}

Carbamazepine is the most frequently observed antiepileptic. Carbamazepine has aromatic rings and amide (Table S11). Amide is not as reactive with ozone because of its electron-drawing nature, causing lower removal efficiencies [151]. However, carbamazepine has a relatively high rate constant $\left(\mathrm{k}_{\mathrm{O} 3}=3 \times 10^{5} \mathrm{M}^{-1} \mathrm{~s}^{-1}\right)$, demonstrating that it is a reactive compound with ozone. This high reactivity of carbamazepine can be attributed to the reactivity of ozone with the (electron donor) double bond that connects the two phenyl moieties [180]. The relatively large $K_{o w}$ and lower aqueous solubility of carbamazepine suggest potential poor biodegradability. Other than ozonation, GAC may be a possible removal process for carbamazepine, because it has a $\mathrm{K}_{\mathrm{oc}}$ of $510 \mathrm{~mL} \cdot \mathrm{g} \mathrm{C}^{-1}$ [179].

\section{5. $\beta$-Blockers}

The most frequently detected $\beta$-blockers are atenolol, metoprolol, and propranolol (Figures S9, S19 and S26). These $\beta$-blockers have similar structures (with an aromatic ring, carboxylic acid, ether, and amines); they also have similar properties (Table S12). Amine functionalities are structural components of $\beta$-blockers that render the compounds highly reactive with respect to ozone [181]. Atenolol has $\mathrm{k}_{\mathrm{O} 3}$ of $1.7 \times 10^{3} \mathrm{M}^{-1} \mathrm{~s}^{-1}$, suggesting a moderate reaction rate with ozonation. The rate constant for propranolol with ozonation is $1.0 \times 10^{5} \mathrm{M}^{-1} \mathrm{~s}^{-1}$, two orders of magnitude greater than that for atenolol, suggesting an increased rate of reaction with ozone. However, the $\log \mathrm{K}_{\mathrm{ow}}$ ranges from 0.16 to 3.48 (Table S12), with varying aqueous solubility as well, indicating potentially unique behavior. Moreover, atenolol has a reported $\mathrm{K}_{\mathrm{oc}}$ ranging from 148 to $1700 \mathrm{~mL} \cdot \mathrm{g} \mathrm{C}^{-1}$ [177], indicating potentially significant removal through GAC. With their varying degrees of reactivity with ozone and different $\log \mathrm{K}_{\mathrm{ow}}$, atenolol and propranolol are selected to represent the group of $\beta$-blockers (Table S12).

\subsection{Lipid Regulators}

Clofibric acid and gemfibrozil are two of the most frequently reported lipid regulators in studies (Figures S10, S19 and S27). The $\mathrm{K}_{\mathrm{ow}}$ varies with clofibric acid $\left(10^{2.88}\right)$ and gemfibrozil $\left(10^{4.77}\right)$, respectively $[51,175]$, indicating hydrophobicity (Table S13). Compared to clofibric acid, gemfibrozil has a relatively lower solubility $(19 \mathrm{mg} / \mathrm{L})$, suggesting poor biodegradability. Therefore, gemfibrozil is selected as an indicator compound. Gemfibrozil, with a $\mathrm{K}_{\mathrm{oc}}$ of $430 \mathrm{~mL} \cdot \mathrm{g} \mathrm{C}^{-1}$ [179], may be easily removed through GAC. Gemfibrozil has structural features, including an aromatic ring, a carboxyl group, and ether (Table S13). The carboxyl group is an electron-withdrawing functional group, indicative of a potentially lower efficiency with ozonation [178]. The rate constant for gemfibrozil is $2.0 \times 10^{3} \mathrm{M}^{-1} \mathrm{~s}^{-1}$ (Table S13), moderately reactive with ozone [151]. 


\subsection{Pesticides}

Atrazine, metolachlor, and DEET were the most frequently detected pesticides (Figures S12 and S29); moreover, they are observed to be recalcitrant in treatment processes as well. Atrazine has a triazine ring but does not have aromatic moieties (electron donors), indicating a slower reaction with ozone, as indicated by the rate constant $\left(\mathrm{k}_{\mathrm{O} 3}=6.0-7.9 \mathrm{M}^{-1} \mathrm{~s}^{-1}\right)$ (Table S14). Furthermore, amide moieties are not reactive with ozone [178]. Both metolachlor and DEET have amide on their aromatic rings, suggesting that they may be difficult to break down with ozone. Atrazine has a large $\mathrm{K}_{\mathrm{ow}}$ and low aqueous solubility, which demonstrates its hydrophobicity and relatively low biodegradability. On the other hand, though metolachlor and DEET have relatively greater aqueous solubilities than atrazine, their $\mathrm{K}_{\mathrm{ow}}$ values are still very large, suggesting poor biodegradability. Moreover, atrazine has a $\mathrm{K}_{\mathrm{oc}}$ ranging from 23 to $101 \mathrm{~mL} \cdot \mathrm{g} \mathrm{C}^{-1}$, lower than the $\mathrm{K}_{\mathrm{oc}}$ reported for DEET $\left(300 \mathrm{~mL} \cdot \mathrm{g} \mathrm{C}^{-1}\right)[179,182,183]$, suggesting lower removal through GAC. With different properties, atrazine, metolachlor, and DEET are selected as the indicator compounds.

\subsection{Steroids}

Cholesterol, coprostanol, $17 \beta$-estradiol, and estrone are the most frequently detected steroids in the aquatic environment (Figures S14, S22 and S32). Because cholesterol and coprostanol have similar structures (alcohol and aliphatic rings), and $17 \beta$-estradiol and estrone share similar structures (phenol and aliphatic rings), cholesterol and $17 \beta$-estradiol are selected to be representative of groups of steroids. The properties of cholesterol and $17 \beta$-estradiol reveal that both have aliphatic moieties, expected to react with molecular ozone, with large rate constants [184] (Table S15). Both steroid hormones and natural steroids have high $\mathrm{K}_{\mathrm{ow}}$ values, indicating hydrophobicity. The aqueous solubilities of these two steroids are also relatively low, suggesting resistance to biodegradability. These properties demonstrate resistance to biological treatment and persistence in water systems. Compared to other compounds studied in this work, $17 \beta$-estradiol has a relatively high $\mathrm{K}_{\mathrm{oc}}\left(3700-10,000 \mathrm{~mL} \cdot \mathrm{g} \mathrm{C}^{-1}\right)$ [185-187], suggesting potentially significant removal through GAC.

\subsection{Other Classes}

Fire retardant TCEP (removal $<20 \%$ ), nicotine metabolite cotinine (removal $<40 \%$ ), and X-ray contrast agent iopromide (removal $<80 \%$ ) are recalcitrant through treatment processes, while the occurrence of psycho-stimulant caffeine and surfactants PFOA and PFOS is frequently reported (Figures S1, S15 and S23). Therefore, they are selected as the indicator compounds. TCEP, caffeine, cotinine, and iopromide have small $\mathrm{K}_{\mathrm{ow}}$ values (Table S16), which suggests that they are hydrophilic compounds, and yet they are frequently detected in water systems, which may result from their broad usage. GAC may not be an effective treatment process for these six compounds, as $\mathrm{K}_{\mathrm{oc}}$ values for TCEP, caffeine, PFOA, PFOS, and cotinine are $67,22,29.51,125.89$, and $130 \mathrm{~mL} \cdot \mathrm{g} \mathrm{C}^{-1}$, respectively, and iopromide has a reported $\mathrm{K}_{\mathrm{oc}}$ value of as low as $0.005 \mathrm{~mL} \cdot \mathrm{g} \mathrm{C} \mathrm{C}^{-1}[150,179,185]$. TCEP has an aliphatic structure with chlorine functional groups, which is polar. TCEP has been shown to be resistant to oxidation using chlorine or ozone [151]. Caffeine has a $\mathrm{k}_{\mathrm{O} 3}$ of $6.4 \times 10^{2} \mathrm{M}^{-1} \mathrm{~s}^{-1}$ (Table S16), indicating a relatively slower reaction with ozone. Caffeine has a purine base (xanthine ring), alkyl groups, and a $\mathrm{C}=\mathrm{C}$ double bond. The $\mathrm{C}=\mathrm{C}$ double bond and alkyl are electron donors, which are amenable to ozonation [178]. PFOA and PFOS have carbon-fluorine (C-F) bonds in their structure. With the most electronegative element fluorine, C-F is a strong bond, which makes PFOA and PFOS two stable CECs and resistant to oxidation and biodegradation [36]. Cotinine has ketone and a pyridine ring. The $\mathrm{k}_{\mathrm{O} 3}$ of iopromide is relatively small, less than $0.8 \mathrm{M}^{-1} \mathrm{~s}^{-1}$. Therefore, the reaction of ozone with iopromide is very slow. Iopromide exhibits three nitrogen atoms as amides, which have very low reactivity to ozone [180]. 


\section{Conclusions}

Based on the criteria of usage, occurrence, persistence in aquatic environments, resistance to treatment, and physicochemical properties, 22 CECs belonging to 13 classes were identified as priority indicator compounds, including:

1. Analgesics: acetaminophen and ibuprofen;

2. Antibiotics: erythromycin, sulfamethoxazole, and trimethoprim;

3. Antidepressants: diazepam and fluoxetine;

4. Antiepileptics: carbamazepine;

5. $\beta$-blockers: atenolol and propranolol;

6. Blood lipid regulators: gemfibrozil;

7. Fire retardants: TCEP;

8. Nicotine metabolites: cotinine;

9. Pesticides: atrazine, metolachlor, and DEET;

10. Steroids: $17 \beta$-estradiol and cholesterol;

11. Surfactants: PFOA and PFOS;

12. Psycho-stimulant: caffeine;

13. X-ray contrast agent: iopromide.

These indicator compounds represent the large number of CECs widely used, are observed at great frequency in aqueous systems, are resistant to treatment, are persistent in the environment, and represent a suite of classes of compounds. Although CECs and therefore indicator compounds have been observed under dilute concentrations (in $\mathrm{ng} / \mathrm{L}$ to $\mu \mathrm{g} / \mathrm{L}$ ) in the water cycle, their effects in the environment cannot be neglected.

The indicator compounds were applied in bench and pilot plant studies to examine the treatability of CECs through conventional and advanced water treatment processes. In our pilot plant study [152], this list was used to understand the optimal combination of existing unit treatment processes in WTP for the removal of CECs through studies of 12 treatment trains. Acetaminophen, ibuprofen, sulfamethoxazole, trimethoprim, carbamazepine, gemfibrozil, caffeine, and $17 \beta$-estradiol achieved greater than $75 \%$ removal in all treatment trains. The most recalcitrant CECs included TCEP and cotinine, with removals of less than $35 \%$ and $80 \%$, respectively, in most of the trains. The $90 \%$ removals were achieved for a number of compounds using trains that included advanced treatment. Specifically, DAF (with either pre- or intermediate oxidation) followed by dual-media filtration and $\mathrm{UV} / \mathrm{H}_{2} \mathrm{O}_{2}$, removed $80 \%$ of the compounds at greater than $90 \%$. However, $90 \%$ removal for all compounds in a single study was only achieved with trains involving DAF in combination with pre- or intermediate ozonation followed by dual-media filtration and virgin GAC. To address the effectiveness of using a more sustainable treatment process that is less energy-intensive and therefore more economical, Zhang et al. (2017) applied bench-scale BAFs as a function of media type, ozonation, and EBCTs [165]. Ibuprofen, trimethoprim, and $17 \beta$-estradiol were removed on average at greater than $80 \%$, while iopromide was the most recalcitrant compound, with removals of $59 \%$ under optimal conditions (i.e., EBCT: $18 \mathrm{~min}$, media: GAC; and pre-ozonation: 3 or $4 \mathrm{mg} / \mathrm{L}$ ). Applying indicator compounds representative of the vast array of CECs observed throughout the water cycle reduces the number of compounds that need to be analyzed and tracked in addressing the efficacy of treatment processes as well as studying transport and fate in the environment.

Supplementary Materials: The following are available online at https:/ / www.mdpi.com/1660-460 $1 / 18 / 3 / 1288 / \mathrm{s} 1$.

Author Contributions: Investigation, writing—original draft preparation, and validation, S.Z.; data curation, S.G.; project administration, J.E.D. and R.F.R.; funding acquisition, writing-review and editing, and supervision, L.A. All authors have read and agreed to the published version of the manuscript. 
Funding: This research was funded by National Science Foundation CBET Award Number 1903597 for the project titled INFEWS: US-CHINA: Biochar-Enabled Biologically Active Filtration System for Sustainable Water Management on Rice Agriculture.

Institutional Review Board Statement: Not applicable.

Informed Consent Statement: Not applicable.

Data Availability Statement: Not applicable.

Acknowledgments: The authors gratefully acknowledge support through National Science Foundation CBET Award Number 1903597 for the project titled INFEWS: US-CHINA: Biochar-Enabled Biologically Active Filtration System for Sustainable Water Management on Rice Agriculture. In addition, this research was supported through a contract with SUEZ North America.

Conflicts of Interest: The authors declare no conflict of interest.

$\begin{array}{ll}\text { Abbreviations } \\ \text { ADI } & \begin{array}{l}\text { acceptable daily intake } \\ \text { biologically active filter }\end{array} \\ \text { BAF } & \text { carbon-fluorine bond } \\ \text { C-F bond } & \text { contaminants of emerging concern } \\ \text { CECs } & \text { consumption rate posing health risk } \\ \text { CRPHR } & \text { dissolved air flotation } \\ \text { DAF } & \text { dichlorodiphenyl-dichloroethylene } \\ \text { DDE } & \text { N,N-diethyl-meta-toluamide } \\ \text { DEET } & \text { empty bed contact time } \\ \text { EBCT } & \text { endocrine-disrupting chemicals } \\ \text { EDC } & \text { granular activated carbon } \\ \text { GAC } & \text { iodinated contrast media agents } \\ \text { ICM } & \text { O } \text { rate constant } \\ \text { kO3 } & \text { moving bed biofilm reactor } \\ \text { MBBR } & \text { natural organic matter } \\ \text { NOM } & \text { hydroxyl radical } \\ \text { OH• } & \text { per- and polyfluoroalkyl substances } \\ \text { PFAS } & \text { perfluorooctanoic acid } \\ \text { PFOA } & \text { perfluorooctane sulfonate } \\ \text { PFOS } & \text { tri(2-chloroethyl) phosphate } \\ \text { TCEP } & \text { tris(1-chloro-2-propyl) phosphate } \\ \text { TCPP } & \text { total organic carbon } \\ \text { TOC } & \text { U.S. Geological Survey } \\ \text { USGS } & \text { water treatment plants } \\ \text { WTP } & \text { wastewater treatment plant } \\ \text { WWTP } & \end{array}$

\section{References}

1. Environmental Protection Agency. Contaminants of Emerging Concern. 2020. Available online: https://www.epa.gov/wqc/ contaminants-emerging-concern-including-pharmaceuticals-and-personal-care-products (accessed on 28 January 2021).

2. Daughton, C.G.; Ternes, T.A. Pharmaceuticals and personal care products in the environment: Agents of subtle change? Environ. Health Perspect. 1999, 107, 907-938. [CrossRef] [PubMed]

3. Farré, M.; Ferrer, I.; Ginebreda, A.; Figueras, M.; Olivella, L.; Tirapu, L.; Vilanova, M.; Barceló, J. Determination of drugs in surface water and wastewater samples by liquid chromatography-mass spectrometry: Methods and preliminary results including toxicity studies with Vibrio fischeri. J. Chromatogr. A 2001, 938, 187-197. [CrossRef]

4. Ternes, T.; Bonerz, M.; Schmidt, T. Determination of neutral pharmaceuticals in wastewater and rivers by liquid chromatographyelectrospray tandem mass spectrometry. J. Chromatogr. A 2001, 938, 175-185. [CrossRef]

5. Kolpin, D.W.; Furlong, E.T.; Meyer, M.T.; Thurman, E.M.; Zaugg, S.D.; Barber, L.B.; Buxton, H.T. Pharmaceuticals, hormones, and other organic wastewater contaminants in u.s. streams, 1999-2000: A national reconnaissance. Environ. Sci. Technol. 2002, 36, 1202-1211. [CrossRef]

6. Batt, A.L.; Kostich, M.S.; Lazorchak, J.M. Analysis of ecologically relevant pharmaceuticals in wastewater and surface water using selective solid-phase extraction and UPLC-MS/MS. Anal. Chem. 2008, 80, 5021-5030. [CrossRef] 
7. Comeau, F.; Surette, C.; Brun, G.; Losier, R. The occurrence of acidic drugs and caffeine in sewage effluents and receiving waters from three coastal watersheds in Atlantic Canada. Sci. Total Environ. 2008, 396, 132-146. [CrossRef]

8. Kleywegt, S.; Pileggi, V.; Yang, P.; Hao, C.; Zhao, X.; Rocks, C.; Thach, S.; Cheung, P.; Whitehead, B. Pharmaceuticals, hormones and bisphenol A in untreated source and finished drinking water in Ontario, Canada-Occurrence and treatment efficiency. Sci. Total Environ. 2011, 409, 1481-1488. [CrossRef]

9. Kostich, M.S.; Batt, A.L.; Lazorchak, J.M. Concentrations of prioritized pharmaceuticals in effluents from 50 large wastewater treatment plants in the US and implications for risk estimation. Environ. Pollut. 2014, 184, 354-359. [CrossRef]

10. Lara-Martín, P.A.; González-Mazo, E.; Petrovic, M.; Barceló, D.; Brownawell, B.J. Occurrence, distribution and partitioning of nonionic surfactants and pharmaceuticals in the urbanized Long Island Sound Estuary (NY). Mar. Pollut. Bull. 2014, 85, 710-719. [CrossRef]

11. Tong, A.Z.; Ghoshdastidar, A.J.; Fox, S. The presence of the top prescribed pharmaceuticals in treated sewage effluents and receiving waters in Southwest Nova Scotia, Canada. Environ. Sci. Pollut. Res. 2015, 22, 689-700. [CrossRef]

12. Writer, J.H.; Ferrer, I.; Barber, L.B.; Thurman, E.M. Widespread occurrence of neuro-active pharmaceuticals and metabolites in 24 Minnesota rivers and wastewaters. Sci. Total Environ. 2013, 461-462, 519-527. [CrossRef] [PubMed]

13. Babić, S.; Asperger, D.; Mutavdžić, D.; Horvat, A.J.M.; Kastelan-Macan, M. Solid phase extraction and HPLC determination of veterinary pharmaceuticals in wastewater. Talanta 2006, 70, 732-738. [CrossRef] [PubMed]

14. Carmona, E.; Andreu, V.; Picó, Y. Occurrence of acidic pharmaceuticals and personal care products in Turia River basin: From waste to drinking water. Sci. Total Environ. 2014, 484, 53-63. [CrossRef] [PubMed]

15. Corada-Fernández, C.; Jiménez-Martínez, J.; Candela, L.; González-Mazo, E.; Lara-Martín, P.A. Occurrence and spatial distribution of emerging contaminants in the unsaturated zone. Case study: Guadalete river basin (Cadiz, Spain). Chemosphere 2015, 119, S131-S137. [CrossRef] [PubMed]

16. Huerta-Fontela, M.; Galceran, M.T.; Ventura, F. Occurrence and removal of pharmaceuticals and hormones through drinking water treatment. Water Res. 2011, 45, 1432-1442. [CrossRef]

17. Koutsouba, V.; Heberer, T.; Fuhrmann, B.; Schmidt-Baumler, K.; Tsipi, D.; Hiskia, A. Determination of polar pharmaceuticals in sewage water of Greece by gas chromatography-mass spectrometry. Chemosphere 2003, 51, 69-75. [CrossRef]

18. Rabiet, M.; Togola, A.; Brissaud, F.; Seidel, J.-L.; Budzinski, H.; Elbaz-Poulichet, F. Consequences of treated water recycling as regards pharmaceuticals and drugs in surface and ground waters of a medium-sized mediterranean catchment. Environ. Sci. Technol. 2006, 40, 5282-5288. [CrossRef]

19. Han, G.H.; Hur, H.G.; Kim, S.D. Ecotoxicological risk of pharmaceuticals from wastewater treatment plants in Korea: Occurrence and toxicity to Daphnia magna. Environ. Toxicol. Chem. 2006, 25, 265-271. [CrossRef]

20. Kim, S.D.; Cho, J.; Kim, I.S.; Vanderford, B.J.; Snyder, S.A. Occurrence and removal of pharmaceuticals and endocrine disruptors in South Korean surface, drinking, and waste waters. Water Res. 2007, 41, 1013-1021. [CrossRef]

21. Kimura, K.; Kameda, Y.; Yamamoto, H.; Nakada, N.; Tamura, I.; Miyazaki, M.; Masunaga, S. Occurrence of preservatives and antimicrobials in Japanese rivers. Chemosphere 2014, 107, 393-399. [CrossRef]

22. Wen, Z.-H.; Chen, L.; Meng, X.-Z.; Duan, Y.-P.; Zhang, Z.-S.; Zeng, E.Y. Occurrence and human health risk of wastewater-derived pharmaceuticals in a drinking water source for Shanghai, East China. Sci. Total Environ. 2014, 490, 987-993. [CrossRef] [PubMed]

23. Zhao, J.-L.; Ying, G.-G.; Wang, L.; Yang, J.-F.; Yang, X.-B.; Yang, L.-H.; Li, X. Determination of phenolic endocrine disrupting chemicals and acidic pharmaceuticals in surface water of the Pearl Rivers in South China by gas chromatography-negative chemical ionization-mass spectrometry. Sci. Total Environ. 2009, 407, 962-974. [CrossRef] [PubMed]

24. Ollers, S.; Singer, H.P.; Fassler, P.; Muller, S.R. Simultaneous quantification of neutral and acidic pharmaceuticals and pesticides at the low-ng/L level in surface and waste water. J. Chromatogr. A 2001, 911, 225-234. [CrossRef]

25. González-Barreiro, C.; Lores, M.; Casais, M.C.; Cela, R. Simultaneous determination of neutral and acidic pharmaceuticals in wastewater by high-performance liquid chromatography-post-column photochemically induced fluorimetry. J. Chromatogr. A 2003, 993, 29-37. [CrossRef]

26. Pereira, L.C.; de Souza, A.O.; Bernardes, M.F.F.; Pazin, M.; Tasso, M.J.; Pereira, P.H.; Dorta, D.J. A perspective on the potential risks of emerging contaminants to human and environmental health. Environ. Sci. Pollut. Res. 2015, 22, 13800-13823. [CrossRef]

27. Schwarzenbach, R.P.; Escher, B.I.; Fenner, K.; Hofstetter, T.B.; Johnson, C.A.; Von Gunten, U.; Wehrli, B. The challenge of micropollutants in aquatic systems. Science 2006, 313, 1072-1077. [CrossRef]

28. Vandenberg, L.N.; Colborn, T.; Hayes, T.B.; Heindel, J.J.; Jacobs, D.R.; Lee, D.-H.; Shioda, T.; Soto, A.M.; vom Saal, F.S.; Welshons, W.V.; et al. Hormones and endocrine-disrupting chemicals: Low-dose effects and non-monotonic dose responses. Endocr. Rev. 2012, 33, 378-455. [CrossRef]

29. Buron, N.; Porceddu, M.; Roussel, C.; Begriche, K.; Trak-Smayra, V.; Gicquel, T.; Fromenty, B.; Borgne-Sanchez, A. Chronic and low exposure to a pharmaceutical cocktail induces mitochondrial dysfunction in liver and hyperglycemia: Differential responses between lean and obese mice. Environ. Toxicol. 2017, 32, 1375-1389. [CrossRef]

30. Czekalski, N.; Berthold, T.; Caucci, S.; Egli, A.; Bürgmann, H. Increased levels of multiresistant bacteria and resistance genes after wastewater treatment and their dissemination into Lake Geneva, Switzerland. Front. Microbiol. 2012, 3, 1-18. [CrossRef]

31. Tetreault, G.R.; Bennett, C.J.; Shires, K.; Knight, B.; Servos, M.R.; McMaster, M.E. Intersex and reproductive impairment of wild fish exposed to multiple municipal wastewater discharges. Aquat. Toxicol. 2011, 104, 278-290. [CrossRef] 
32. Caldwell, D.J.; Mastrocco, F.; Nowak, E.; Johnston, J.; Yekel, H.; Pfeiffer, D.; Hoyt, M.; DuPlessie, B.M.; Anderson, P.D. An Assessment of potential exposure and risk from estrogens in drinking water. Environ. Health Perspect. 2010, 118, 338-344. [CrossRef] [PubMed]

33. Murray, K.E.; Thomas, S.M.; Bodour, A.A. Prioritizing research for trace pollutants and emerging contaminants in the freshwater environment. Environ. Pollut. 2010, 158, 3462-3471. [CrossRef] [PubMed]

34. Schriks, M.; Heringa, M.B.; van der Kooi, M.M.E.; de Voogt, P.; van Wezel, A.P. Toxicological relevance of emerging contaminants for drinking water quality. Water Res. 2010, 44, 461-476. [CrossRef]

35. Schwab, B.W.; Hayes, E.P.; Fiori, J.M.; Mastrocco, F.J.; Roden, N.M.; Cragin, D.; Meyerhoff, R.D.; D'Aco, V.J.; Anderson, P.D. Human pharmaceuticals in US surface waters: A human health risk assessment. Regul. Toxicol. Pharmacol. 2005, 42, 296-312. [CrossRef] [PubMed]

36. Environmental Protection Agency. Drinking Water Health Advisory for Perfluorooctanoic Acid (PFOA) 2016. Available online: https:/ / www.epa.gov/sites/production/files/2016-05/documents/pfoa_health_advisory_final-plain.pdf (accessed on 19 December 2020).

37. Environmental Protection Agency. Drinking Water Health Advisory for Perfluorooctane Sulfonate (PFOS). 2016. Available online: https:/ /www.epa.gov/sites/production/files/2016-05/documents/pfos_health_advisory_final-plain.pdf (accessed on 19 December 2020).

38. Daughton, C.G. Pharmaceuticals in the environment: Sources and their management. In Analysis, Fate and Removal of Pharmaceuticals in the Water Cycle, 1st ed.; Barcelo, D., Petrovic, M., Eds.; Elsevier Science: Amsterdam, The Netherlands, 2007; Volume 62, pp. $1-58$.

39. Lienert, J.; Guedel, K.; Escher-Beate, I. Screening method for ecotosicological hazard Assessment of 42 pharmaceuticals considering human metabolism and excretory routes. Environ. Sci. Technol. 2007, 41, 4471-4478. [CrossRef]

40. Graves, G.A.; Wan, Y.; Fike, D.L. Water quality characteristics of storm water from major land uses in South Florida. JAWRA J. Am. Water Resour. Assoc. 2004, 40, 1405-1419. [CrossRef]

41. $\mathrm{Xu}, \mathrm{J} . ; \mathrm{Wu}, \mathrm{L} . ;$ Chen, W.; Jiang, P.; Chang, A.C.-S. Pharmaceuticals and personal care products (PPCPs), and endocrine disrupting compounds (EDCS) in runoff from a potato field irrigated with treated wastewater in Southern California. J. Health Sci. 2009, 55, 306-310. [CrossRef]

42. Brown, K.D.; Kulis, J.; Thomson, B.; Chapman, T.H.; Mawhinney, D.B. Occurrence of antibiotics in hospital, residential, and dairy effluent, municipal wastewater, and the Rio Grande in New Mexico. Sci. Total Environ. 2006, 366, 772-783. [CrossRef]

43. Oliveira, T.S.; Murphy, M.; Mendola, N.; Wong, V.; Carlson, D.; Waring, L. Characterization of pharmaceuticals and personal care products in hospital effluent and waste water influent/effluent by direct-injection LC-MS-MS. Sci. Total Environ. 2015, 518, 459-478. [CrossRef]

44. Weissbrodt, D.; Koval'Ová, L.; Ort, C.; Pazhepurackel, V.; Moser, R.; Hollender, J.; Siegrist, H.; McArdell, C.S. Mass flows of X-ray contrast media and cytostatics in hospital wastewater. Environ. Sci. Technol. 2009, 43, 4810-4817. [CrossRef]

45. Yuan, S.; Jiang, X.; Xia, X.; Zhang, H.; Zheng, S. Detection, occurrence and fate of 22 psychiatric pharmaceuticals in psychiatric hospital and municipal wastewater treatment plants in Beijing, China. Chemosphere 2013, 90, 2520-2525. [CrossRef] [PubMed]

46. IMS Institute for Healthcare Informatics. Medicines Use and Spending Shifts: A Review of the Use of Medicines in the U.S. in 2014; IMS Drive: Parsippany, NJ, USA, 2015.

47. IMS Institute for Healthcare Informatics. Medicines Use and Spending in the U.S: A Review of 2015 and Outlook to 2020; IMS Drive: Parsippany, NJ, USA, 2016.

48. Grand View Research. Contrast Media/Contrast Agents Market Analysis, by Agent Type (Iodinated, Barium-based, GadoliniumBased, Microbubble), by Modality (X-ray/CT, MRI, Ultrasound), by Application, and Segment Forecasts 2018-2025. Available online: https://www.grandviewresearch.com/industry-analysis/contrast-media-contrast-agents-market (accessed on 31 January 2021).

49. Gerrity, D.; Gamage, S.; Holady, J.C.; Mawhinney, D.B.; Quiñones, O.; Trenholm, R.A.; Snyder, S.A. Pilot-scale evaluation of ozone and biological activated carbon for trace organic contaminant mitigation and disinfection. Water Res. 2011, 45, 2155-2165. [CrossRef] [PubMed]

50. Oppenheimer, J.; Eaton, A.; Badruzzaman, M.; Haghani, A.W.; Jacangelo, J.G. Occurrence and suitability of sucralose as an indicator compound of wastewater loading to surface waters in urbanized regions. Water Res. 2011, 45, 4019-4027. [CrossRef] [PubMed]

51. Snyder, S.A.; Wert, E.C.; Lei, H.; Westerhoff, P.; Yoon, Y. Removal of EDCs and Pharmaceuticals in Drinking and Reuse Treatment Processes; American Water Works Association Research Foundation: Denver, CO, USA, 2007.

52. Fairbairn, D.J.; Karpuzcu, M.E.; Arnold, W.A.; Barber, B.L.; Kaufenberg, E.F.; Koskinen, W.C.; Novak, P.J.; Rice, P.J.; Swackhamer, D.L. Sources and transport of contaminants of emerging concern: A two-year study of occurrence and spatiotemporal variation in a mixed land use watershed. Sci. Total Environ. 2016, 551-552, 605-613. [CrossRef] [PubMed]

53. Grube, A.; Donaldson, D.; Kiely, T.; Wu, L. Pesticides Industry Sales and Usage-2006 and 2007 Market Estimates; U.S. Environmental Protection Agency: Washington, DC, USA, 2011.

54. Kiely, T.; Donaldson, D.; Grube, A. Pesticides Industry Sales and Usage-2006 and 2007 Market Estimates; U.S. Environmental Protection Agency: Washington, DC, USA, 2004. 
55. Benotti, M.J.; Trenholm, R.A.; Vanderford, B.J.; Holady, J.C.; Stanford, B.D.; Snyder, S.A. Pharmaceuticals and endocrine disrupting compounds in U.S. drinking water. Environ. Sci. Technol. 2009, 43, 597-603. [CrossRef] [PubMed]

56. Glassmeyer, S.T.; Furlong, E.T.; Kolpin, D.W.; Cahill, J.D.; Zaugg, S.D.; Werner, S.L.; Meyer, M.T.; Kryak, D.D. Transport of chemical and microbial compounds from known wastewater discharges: Potential for use as indicators of human fecal contamination. Environ. Sci. Technol. 2005, 39, 5157-5169. [CrossRef] [PubMed]

57. Padhye, L.P.; Yao, H.; Kung'u, F.T.; Huang, C.-H. Year-long evaluation on the occurrence and fate ofpharmaceuticals, personal care products, andendocrine disrupting chemicals in an urban drinking water treatment plant. Water Res. 2014, 51, 266-276. [CrossRef] [PubMed]

58. Sengupta, A.; Lyons, J.M.; Smith, D.J.; Drewes, J.E.; Snyder, S.A.; Heil, A.; Maruya, K.A. The occurrence and fate of chemicals of emerging concern in coastal urban rivers receiving discharge of treated municipal wastewater effluent. Environ. Toxicol. Chem. 2014, 33, 350-358. [CrossRef]

59. Ackerman, D.; Schiff, K. Modeling storm water mass emissions to the Southern California Bight. J. Environ. Eng. 2003, 129, 308-317. [CrossRef]

60. Boithias, L.; Sauvage, S.; Taghavi, L.; Merlina, G.; Probst, J.-L.; Sánchez-Pérez, J.M. Occurrence of metolachlor and trifluralin losses in the Save river agricultural catchment during floods. J. Hazard. Mater. 2011, 196, 210-219. [CrossRef]

61. Müller, K.; Bach, M.; Hartmann, H.; Spiteller, M.; Frede, H.-G. Point-and nonpoint-source pesticide contamination in the Zwester Ohm Catchment, Germany. J. Environ. Qual. 2002, 31, 309-318. [CrossRef] [PubMed]

62. Wittmer, I.K.; Bader, H.-P.; Scheidegger, R.; Singer, H.; Lück, A.; Hanke, I.; Carlsson, C.; Stamm, C. Significance of urban and agricultural land use for biocide and pesticide dynamics in surface waters. Water Res. 2010, 44, 2850-2862. [CrossRef] [PubMed]

63. Bartelt-Hunt, S.L.; Snow, D.D.; Damon, T.; Shockley, J.; Hoagland, K. The occurrence of illicit and therapeutic pharmaceuticals in wastewater effluent and surface waters in Nebraska. Environ. Pollut. 2009, 157, 786-791. [CrossRef] [PubMed]

64. Bisceglia, K.J.; Yu, J.T.; Coelhan, M.; Bouwer, E.J.; Roberts, A.L. Trace determination of pharmaceuticals and other wastewaterderived micropollutants by solid phase extraction and gas chromatography/mass spectrometry. J. Chromatogr. A 2010, 1217, 558-564. [CrossRef]

65. Boyd, G.R.; Reemtsma, H.; Grimm, D.A.; Mitra, S. Pharmaceuticals and personal care products (PPCPs) in surface and treated waters of Louisiana, USA and Ontario, Canada. Sci. Total Environ. 2003, 311, 135-149. [CrossRef]

66. Bulloch, D.N.; Nelson, E.D.; Carr, S.A.; Wissman, C.R.; Armstrong, J.L.; Schlenk, D.; Larive, C.K. Occurrence of halogenated transformation products of selected pharmaceuticals and personal care products in secondary and tertiary treated wastewaters from Southern California. Environ. Sci. Technol. 2015, 49, 2044-2051. [CrossRef] [PubMed]

67. Chiaia, A.C.; Banta-Green, C.; Field, J. Eliminating solid phase extraction with large-volume injection LC/MS/MS: Analysis of illicit and legal drugs and human urine indicators in US wastewaters. Environ. Sci. Technol. 2008, 42, 8841-8848. [CrossRef] [PubMed]

68. Elmoznino, J.; Vlahos, P.; Whitney, M. Occurrence and partitioning behavior of perfluoroalkyl acids in wastewater effluent discharging into the Long Island Sound. Environ. Pollut. 2018, 243, 453-461. [CrossRef] [PubMed]

69. Gao, P.; Ding, Y.; Li, H.; Xagoraraki, I. Occurrence of pharmaceuticals in a municipal wastewater treatment plant: Mass balance and removal processes. Chemosphere 2012, 88, 17-24. [CrossRef]

70. Gross, B.; Montgomery-Brown, J.; Naumann, A.; Reinhard, M. Occurrence and fate of pharmaceuticals and alkylphenol ethoxylate metabolites in an effluent-dominated river and wetland. Environ. Toxicol. Chem. 2004, 23, 2074-2083. [CrossRef]

71. Huggett, D.B.; Khan, I.A.; Foran, C.M.; Schlenk, D. Determination of beta-adrenergic receptor blocking pharmaceuticals in United States wastewater effluent. Environ. Pollut. 2003, 121, 199-205. [CrossRef]

72. Kwon, J.-W.; Rodriguez, J.M. Occurrence and removal of selected pharmaceuticals and personal care products in three wastewatertreatment plants. Arch. Environ. Contam. Toxicol. 2014, 66, 538-548. [CrossRef] [PubMed]

73. Loganathan, B.G.; Sajwan, K.S.; Sinclair, E.; Kumar, K.S.; Kannan, K. Perfluoroalkyl sulfonates and perfluorocarboxylates in two wastewater treatment facilities in Kentucky and Georgia. Water Res. 2007, 41, 4611-4620. [CrossRef] [PubMed]

74. Spongberg, A.L.; Witter, J.D. Pharmaceutical compounds in the wastewater process stream in Northwest Ohio. Sci. Total Environ. 2008, 397, 148-157. [CrossRef]

75. Subedi, B.; Kannan, K. Occurrence and fate of select psychoactive pharmaceuticals and antihypertensives in two wastewater treatment plants in New York State, USA. Sci. Total Environ. 2015, 514, 273-280. [CrossRef]

76. Vanderford, B.J.; Snyder, S.A. Analysis of pharmaceuticals in water by isotope dilution liquid chromatography/tandem mass spectrometry. Environ. Sci. Technol. 2006, 40, 7312-7320. [CrossRef]

77. Yang, X.; Flowers, R.C.; Weinberg, H.S.; Singer, P.C. Occurrence and removal of pharmaceuticals and personal care products (PPCPs) in an advanced wastewater reclamation plant. Water Res. 2011, 45, 5218-5228. [CrossRef]

78. Yu, J.T.; Bouwer, E.J.; Coelhan, M. Occurrence and biodegradability studies of selected pharmaceuticals and personal care products in sewage effluent. Agric. Water Manag. 2006, 86, 72-80. [CrossRef]

79. Yu, Y.; Wu, L.; Chang, A. Seasonal variation of endocrine disrupting compounds, pharmaceuticals and personal care products in wastewater treatment plants. Sci. Total Environ. 2013, 442, 310-316. [CrossRef]

80. Ter Laak, T.L.; van der Aa, M.; Houtman, C.J.; Stoks, P.G.; van Wezel, A.P. Relating environmental concentrations of pharmaceuticals to consumption: A mass balance approach for the river Rhine. Environ. Int. 2010, 36, 403-409. [CrossRef] 
81. Luo, Y.; Guo, W.; Ngo, H.H.; Nghiem, L.D.; Hai, F.I.; Zhang, J.; Liang, S.; Wang, X.C. A review on the occurrence of micropollutants in the aquatic environment and their fate and removal during wastewater treatment. Sci. Total Environ. 2014, 473-474, 619-641. [CrossRef]

82. Blair, B.D.; Crago, J.P.; Hedman, C.J.; Klaper, R.D. Pharmaceuticals and personal care products found in the Great Lakes above concentrations of environmental concern. Chemosphere 2013, 93, 2116-2123. [CrossRef] [PubMed]

83. Chase, D.A.; Karnjanapiboonwong, A.; Fang, Y.; Cobb, G.P.; Morse, A.N.; Anderson, T.A. Occurrence of synthetic musk fragrances in effluent and non-effluent impacted environments. Sci. Total Environ. 2012, 416, 253-260. [CrossRef] [PubMed]

84. Guo, Y.C.; Krasner, S.W. Occurrence of primidone, carbamazepine, caffeine, and precursors for $N$-nitrosodimethylamine in drinking water sources impacted by wastewater. JAWRA J. Am. Water Resour. Assoc. 2009, 45, 58-67. [CrossRef]

85. Maruya, K.A.; Dodder, N.G.; Sengupta, A.; Smith, D.J.; Lyons, J.M.; Heil, A.T.; Drewes, J.E. Multimedia screening of contaminants of emerging concern (CECs) in coastal urban watersheds in southern California (USA). Environ. Toxicol. Chem. 2016, 35, 1986-1994. [CrossRef] [PubMed]

86. Kim, S.-C.; Carlson, K. Occurrence of ionophore antibiotics in water and sediments of a mixed-landscape watershed. Water Res. 2006, 40, 2549-2560. [CrossRef]

87. Matamoros, V.; Arias, C.A.; Nguyen, L.X.; Salvadó, V.; Brix, H. Occurrence and behavior of emerging contaminants in surface water and a restored wetland. Chemosphere 2012, 88, 1083-1089. [CrossRef]

88. Tabe, S.; Jamal, T.; Seth, R.; Yue, C.; Yang, P.; Zhao, X.; Schweitzer, L. ECs and EDC-Occurrence in the Detroit River and Their Removal by Ozonation; Water Research Foundation: Denver, CO, USA, 2009.

89. Dougherty, J.A.; Swarzenski, P.W.; Dinicola, R.S.; Reinhard, M. Occurrence of herbicides and pharmaceutical and personal care products in surface water and groundwater around Liberty Bay, Puget Sound, Washington. J. Environ. Qual. 2010, 39, 1173-1180. [CrossRef]

90. Singh, S.P.; Azua, A.; Chaudhary, A.; Khan, S.; Willett, K.L.; Gardinali, P.R. Occurrence and distribution of steroids, hormones and selected pharmaceuticals in South Florida coastal environments. Ecotoxicology 2009, 19, 338-350. [CrossRef]

91. Anderson, R.H.; Long, G.C.; Porter, R.C.; Anderson, J.K. Occurrence of select perfluoroalkyl substances at U.S. Air Force aqueous film-forming foam release sites other than fire-training areas: Field-validation of critical fate and transport properties. Chemosphere 2016, 150, 678-685. [CrossRef]

92. Bai, X.; Son, Y. Perfluoroalkyl substances (PFAS) in surface water and sediments from two urban watersheds in Nevada, USA. Sci. Total Environ. 2021, 751, 141622. [CrossRef] [PubMed]

93. Batt, A.L.; Kincaid, T.M.; Kostich, M.S.; Lazorchak, J.M.; Olsen, A.R. Evaluating the extent of pharmaceuticals in surface waters of the United States using a National-scale rivers and streams assessment survey. Environ. Toxicol. Chem. 2016, 35, 874-881. [CrossRef] [PubMed]

94. Boyd, G.R.; Grimm, D.A. Occurrence of pharmaceutical contaminants and screening of treatment alternatives for southeastern Louisiana. Ann. N. Y. Acad. Sci. 2006, 948, 80-89. [CrossRef] [PubMed]

95. Crone, B.C.; Speth, T.F.; Wahman, D.G.; Smith, S.J.; Abulikemu, G.; Kleiner, E.J.; Pressman, J.G. Occurrence of per- and polyfluoroalkyl substances (PFAS) in source water and their treatment in drinking water. Crit. Rev. Environ. Sci. Technol. 2019, 49, 2359-2396. [CrossRef] [PubMed]

96. Goodrow, S.M.; Ruppel, B.; Lippincott, R.L.; Post, G.B.; Procopio, N.A. Investigation of levels of per-fluoroalkyl substances in surface water, sediment and fish tissue in New Jersey, USA. Sci. Total Environ. 2020, 729, 138839. [CrossRef] [PubMed]

97. Konwick, B.J.; Tomy, G.T.; Ismail, N.; Peterson, J.T.; Fauver, R.J.; Higginbotham, D.; Fisk, A.T. Concentrations and patterns of perfluoroalkyl acids in Georgia, USA surface waters near and distant to a major use source. Environ. Toxicol. Chem. 2008, 27, 2011-2018. [CrossRef]

98. Post, G.B.; Louis, J.B.; Lippincott, R.L.; Procopio, N.A. Occurrence of perfluorinated compounds in raw water from new jersey public drinking water systems. Environ. Sci. Technol. 2013, 47, 13266-13275. [CrossRef]

99. Procopio, N.A.; Karl, R.; Goodrow, S.M.; Maggio, J.; Louis, J.B.; Atherholt, T.B. Occurrence and source identification of perfluoroalkyl acids (PFAAs) in the Metedeconk River Watershed, New Jersey. Environ. Sci. Pollut. Res. 2017, 24, 27125-27135. [CrossRef]

100. Sinclair, E.; Mayack, D.T.; Roblee, K.; Yamashita, N.; Kannan, K. Occurrence of perfluoroalkyl surfactants in water, fish, and birds from New York State. Arch. Environ. Contam. Toxicol. 2006, 50, 398-410. [CrossRef]

101. Vedagiri, U.K.; Anderson, R.H.; Loso, H.M.; Schwach, C.M. Ambient levels of PFOS and PFOA in multiple environmental media. Remediat. J. 2018, 28, 9-51. [CrossRef]

102. Zhang, X.; Lohmann, R.; Dassuncao, C.; Hu, X.C.; Weber, A.K.; Vecitis, C.D.; Sunderland, E.M. Source Attribution of poly- and perfluoroalkyl substances (PFASs) in surface waters from Rhode Island and the New York metroolitan area. Environ. Sci. Technol. Lett. 2016, 3, 316-321. [CrossRef] [PubMed]

103. Focazio, M.J.; Kolpin, D.W.; Barnes, K.K.; Furlong, E.T.; Meyer, M.T.; Zaugg, S.D.; Barber, L.B.; Thurman, M.E. A national reconnaissance for pharmaceuticals and other organic wastewater contaminants in the United States-II) Untreated drinking water sources. Sci. Total Environ. 2008, 402, 201-216. [CrossRef] [PubMed]

104. Stackelberg, P.E.; Furlong, E.T.; Meyer, M.T.; Zaugg, B.D.; Henderson, A.K.; Reissman, D.B. Persistence of pharmaceutical compounds and other organic wastewater contaminants in a conventional drinking-water-treatment plant. Sci. Total Environ. 2004, 329, 99-113. [CrossRef] 
105. Loraine, G.A.; Pettigrove, M.E. Seasonal variations in concentrations of pharmaceuticals and personal care products in drinking water and reclaimed wastewater in Southern California. Environ. Sci. Technol. 2006, 40, 687-695. [CrossRef] [PubMed]

106. Fram, M.S.; Belitz, K. Occurrence and concentrations of pharmaceutical compounds in groundwater used for public drinkingwater supply in California. Sci. Total Environ. 2011, 409, 3409-3417. [CrossRef]

107. Snyder, S.A. Occurrence, treatment, and toxicological relevance of EDCs and pharmaceuticals in water. Ozone Sci. Eng. 2008, 30, 65-69. [CrossRef]

108. Boone, J.S.; Vigo, C.; Boone, T.; Byrne, C.; Ferrario, J.; Benson, R.; Donohue, J.; Simmons, J.E.; Kolpin, D.W.; Furlong, E.T.; et al. Per- and polyfluoroalkyl substances in source and treated drinking waters of the United States. Sci. Total Environ. 2019, 653, 359-369. [CrossRef]

109. Quiñones, O.; Snyder, S.A. Occurrence of perfluoroalkyl carboxylates and sulfonates in drinking water utilities and related waters from the United States. Environ. Sci. Technol. 2009, 43, 9089-9095. [CrossRef]

110. Sun, M.; Arevalo, E.; Strynar, M.; Lindstrom, A.; Richardson, M.; Kearns, B.; Pickett, A.; Smith, C.; Knappe, D.R.U. Legacy and emerging perfluoroalkyl substances are important drinking water contaminants in the Cape Fear River Watershed of North Carolina. Environ. Sci. Technol. Lett. 2016, 3, 415-419. [CrossRef]

111. Guerra, P.; Kim, M.; Shah, A.; Alaee, M.; Smyth, S. Occurrence and fate of antibiotic, analgesic/anti-inflammatory, and antifungal compounds in five wastewater treatment processes. Sci. Total Environ. 2014, 473-474, 235-243. [CrossRef]

112. Tauxe-Wuersch, A.; De Alencastro, L.F.; Grandjean, D.; Tarradellas, J. Occurrence of several acidic drugs in sewage treatment plants in Switzerland and risk assessment. Water Res. 2005, 39, 1761-1772. [CrossRef] [PubMed]

113. Casas, M.E.; Chhetri, R.K.; Ooi, G.; Hansen, K.M.S.; Litty, K.; Christensson, M.; Kragelund, C.; Andersen, H.R.; Bester, K. Biodegradation of pharmaceuticals in hospital wastewater by staged moving bed biofilm reactors (MBBR). Water Res. 2015, 83, 293-302. [CrossRef] [PubMed]

114. Rosal, R.; Rodríguez, A.; Perdigón-Melón, J.A.; Petre, A.; García-Calvo, E.; Gómez, M.J.; Agüera, A.; Fernández-Alba, A.R. Occurrence of emerging pollutants in urban wastewater and their removal through biological treatment followed by ozonation. Water Res. 2010, 44, 578-588. [CrossRef] [PubMed]

115. Bueno, M.J.M.; Gomez, M.J.; Herrera, S.; Hernando, M.D.; Agüera, A.; Fernández-Alba, A.R. Occurrence and persistence of organic emerging contaminants and priority pollutants in five sewage treatment plants of Spain: Two years pilot survey monitoring. Environ. Pollut. 2012, 164, 267-273. [CrossRef] [PubMed]

116. Gómez, M.J.; Martínez Bueno, M.J.; Lacorte, S.; Fernández-Alba, A.R.; Agüera, A. Pilot survey monitoring pharmaceuticals and related compounds in a sewage treatment plant located on the Mediterranean coast. Chemosphere 2007, 66, 993-1002. [CrossRef]

117. Khanzada, N.K.; Farid, M.U.; Kharraz, J.A.; Choi, J.; Tang, C.Y.; Nghiem, L.D.; Jang, A.; An, A.K. Removal of organic micropollutants using advanced membrane-based water and wastewater treatment: A review. J. Membr. Sci. 2020, 598, 117672. [CrossRef]

118. Blair, B.D.; Nikolaus, A.; Hedman, C.; Klaper, R.; Grundl, T. Evaluating the degradation, sorption, and negative mass balances of pharmaceuticals and personal care products during wastewater treatment. Chemosphere 2015, 134, 395-401. [CrossRef]

119. Jones, O.A.H.; Voulvoulis, N.; Lester, J. The occurrence and removal of selected pharmaceutical compounds in a sewage treatment works utilising activated sludge treatment. Environ. Pollut. 2007, 145, 738-744. [CrossRef]

120. Lishman, L.; Smyth, S.A.; Sarafin, K.; Kleywegt, S.; Toito, J.; Peart, T.; Lee, B.; Servos, M.; Beland, M.; Seto, P. Occurrence and reductions of pharmaceuticals and personal care products and estrogens by municipal wastewater treatment plants in Ontario, Canada. Sci. Total Environ. 2006, 367, 544-558. [CrossRef]

121. Zupanc, M.; Kosjek, T.; Petkovšek, M.; Dular, M.; Kompare, B.; Širok, B.; Blažeka, Ž.; Heath, E. Removal of pharmaceuticals from wastewater by biological processes, hydrodynamic cavitation and UV treatment. Ultrason. Sonochem. 2013, 20, 1104-1112 [CrossRef]

122. Santos, J.L.; Aparicio, I.; Callejón, M.; Alonso, E. Occurrence of pharmaceutically active compounds during 1-year period in wastewaters from four wastewater treatment plants in Seville (Spain). J. Hazard. Mater. 2009, 164, 1509-1516. [CrossRef] [PubMed]

123. Barber, L.B.; Keefe, S.H.; Antweiler, R.C.; Taylor, H.E.; Wass, R.D. Accumulation of Contaminants in fish from wastewater treatment wetlands. Environ. Sci. Technol. 2006, 40, 603-611. [CrossRef] [PubMed]

124. Brozinski, J.-M.; Lahti, M.; Meierjohann, A.; Oikari, A.; Kronberg, L. The anti-inflammatory drugs diclofenac, naproxen and ibuprofen are found in the bile of wild fish caught downstream of a wastewater treatment plant. Environ. Sci. Technol. 2013, 47, 342-348. [CrossRef]

125. Jarvis, A.L.; Bernot, M.J.; Bernot, R.J. Relationships between the psychiatric drug carbamazepine and freshwater macroinvertebrate community structure. Sci. Total Environ. 2014, 496, 499-509. [CrossRef] [PubMed]

126. Guardabassi, L.; Wong, D.M.L.F.; Dalsgaard, A. The effects of tertiary wastewater treatment on the prevalence of antimicrobial resistant bacteria. Water Res. 2002, 36, 1955-1964. [CrossRef]

127. Lateef, A. The microbiology of a pharmaceutical effluent and its public health implications. World J. Microbiol. Biotechnol. 2004, 20, 167-171. [CrossRef]

128. Silvia, J.; Castillo, G.; Callejas, L.; Lopez, H.; Olmos, J. Frequency of transferable multiple antibiotic resistance amongst coliform bacteria isolated from a treated sewage effluent in Antofagasta, Chile. Electron. J. Biotechnol. 2006, 9, 533-540. [CrossRef]

129. Silva, M.F.; Vaz-Moreira, I.; Gonzalez-Pajuelo, M.; Nunes, O.C.; Manaia, C.M. Antimicrobial resistance patterns in Enterobacteriacease isolated from an urban wastewater treatment plant. FEMS Microbiol. Ecol. 2007, 60, 166-176. [CrossRef] 
130. Young, S.; Juhl, A.; O'Mullan, G.D. Antibiotic-resistant bacteria in the Hudson River Estuary linked to wet weather sewage contamination. J. Water Health 2013, 11, 297-310. [CrossRef]

131. Hinck, J.E.; Blazer, V.S.; Schmitt, C.J.; Papoulias, D.M.; Tillitt, D.E. Wildspread occurrence of inter-sex in black basses (Micropterus spp.) from U.S. rivers, 1995-2004. Aquat. Toxicol. 2009, 95, 60-70.

132. Kidd, K.A.; Blanchfield, P.J.; Mills, K.H.; Palace, V.P.; Evans, R.E.; Lazorchak, J.M.; Flick, R.W. Collapse of a fish population after exposure to a synthetic estrogen. Proc. Natl. Acad. Sci. USA 2007, 104, 8897-8901. [CrossRef] [PubMed]

133. Orlando, E.F.; Kolok, A.S.; Binzcik, G.A.; Gates, J.L.; Horton, M.K.; Lambright, C.S.; Gray, L.E.; Soto, A.M.; Guillette, L.J. Endocrine-disrupting effects of cattle feedlot effluent on an aquatic sentinel species, the fathead minnow. Environ. Health Perspect. 2004, 112, 353-358. [CrossRef] [PubMed]

134. Almeida, Â.; Freitas, R.; Calisto, V.; Esteves, V.I.; Schneider, R.J.; Soares, A.M.; Figueira, E. Chronic toxicity of the antiepileptic carbamazepine on the clam Ruditapes philippinarum. Comp. Biochem. Physiol. Part C Toxicol. Pharmacol. 2015, 172-173, 26-35. [CrossRef] [PubMed]

135. McRae, N.K.; Glover, C.N.; Burket, S.R.; Brooks, B.W.; Gaw, S. Acute exposure to an environmentally relevant concentration of diclofenac elicits oxidative stress in the culturally important galaxiid fish Galaxias maculatus. Environ. Toxicol. Chem. 2018, 37, 224-235. [CrossRef] [PubMed]

136. Mu, X.; Wang, K.; Chen, X.; Pang, S.; Zhu, L.; Yang, Y.; Zhang, J.; Li, X.; Wang, C. Impact of environmental concentrations of beta-cypermethrin on the antioxidant system in the brain and liver of zebrafish (Danio rerio). Chem. Ecol. 2014, 30, 643-652. [CrossRef]

137. Stancova, V.; Plhalova, L.; Blahova, J.; Zivna, D.; Bartoskova, M.; Siroka, Z.; Marsalek, P.; Svobodova, Z. Effects of the pharmaceutical contaminants ibuprofen, diclofenac, and carbamazepine alone, and in combination, on oxidative stress parameters in early life stages of tench (Tinca tinca). Vet. Med. 2017, 62, 90-97. [CrossRef]

138. Pal, A.; He, Y.; Jekel, M.; Reinhard, M.; Gin, K.Y.H. Emerging contaminants of public health significance as water quality indicator compounds in the urban water cycle. Environ. Int. 2014, 71, 46-62. [CrossRef]

139. Ash, R.J.; Mauch, B.; Moulder, W.; Morgan, M. Antibiotic-resistant bacteria in U.S. rivers. In Proceedings of the America Society for Microbiology 99th Annual Meeting, Chicago, IL, USA, 30 May-3 June 1999.

140. Zhang, Y.; Marrs, C.F.; Simon, C.; Xi, C. Wastewater treatment contributes to selective increase of antibiotic resistance among Acinetobacter spp. Sci. Total Environ. 2009, 407, 3702-3706. [CrossRef]

141. Jobling, S.; Beresford, N.; Nolan, M.; Rodgers-Gray, T.; Brighty, G.C.; Sumpter, J.P.; Tyler, C.R. Altered sexual maturation and gamete production in wild roach (Rutius rutilus) living in rivers that receive treated sewage effluents. Biol. Reprod. 2002, 66, 272-281. [CrossRef]

142. Jobling, S.; Burn, R.W.; Thorpe, K.; Williams, R.; Tyler, C. Statistical modeling suggests that anti-androgens in effluents from wastewater treatment works contribute to widespread sexual disruption in fish living in English rivers. Environ. Health Perspect. 2009, 117, 797-802. [CrossRef]

143. Obling, S.J.; Nolan, M.; Tyler, C.R.; Brighty, G.; Sumpter, J.P. Widespread sexual disruption in wild fish. Environ. Sci. Technol. 1998, 32, 2498-2506. [CrossRef]

144. Niemuth, N.J.; Klaper, R.D. Emerging wastewater contaminant metformin causes intersex and reduced fecundity in fish. Chemosphere 2015, 135, 38-45. [CrossRef] [PubMed]

145. Yang, M.; Liu, S.; Hu, L.; Zhan, J.; Lei, P.; Wu, M. Effects of the antidepressant, mianserin, on early development of fish embryos at low environmentally relevant concentrations. Ecotoxicol. Environ. Saf. 2018, 150, 144-151. [CrossRef] [PubMed]

146. Howell, W.M.; Black, D.A.; Bortone, S.A. Abnormal expression of secondary sex characters in a population of mosquitofish, Gambusia affinis holbrookii: Evidence for environmentally induced masculinization. Copeia 1980, 4, 676-681. [CrossRef]

147. Rodgers-Gray, T.P.; Jobling, S.; Kelly, C.; Morris, S.; Brighty, G.; Waldock, M.J.; Sumpter, J.P.; Tyler, C.R. Exposure of juvenile roach (Rutilus rutilus) to treated sewage effluent induces dose-dependent and persistent disruption in gonadal duct development. Environ. Sci. Technol. 2001, 35, 462-470. [CrossRef]

148. Appleman, T.D.; Higgins, C.P.; Quiñones, O.; Vanderford, B.J.; Kolstad, C.; Zeigler-Holady, J.C.; Dickenson, E.R.V. Treatment of poly- and perfluoroalkyl substances in U.S. full-scale water treatment systems. Water Res. 2014, 51, 246-255. [CrossRef]

149. Pramanik, B.K. Occurrence of perfluoroalkyl and polyfluoroalkyl substances in the water environment and their removal in a water treatment process. J. Water Reuse Desalin. 2015, 5, 196-210. [CrossRef]

150. Rahman, M.F.; Yanful, E.K.; Jasim, S.Y.; Bragg, L.M.; Servos, M.R.; Ndiongue, S.; Borikar, D. Advanced oxidation treatment of drinking water: Part, I. Occurrence and removal of pharmaceuticals and endocrine-disrupting compounds from Lake Huron water. Ozone Sci. Eng. 2010, 32, 217-229. [CrossRef]

151. Westerhoff, P.; Yoon, Y.; Snyder, S.; Wert, E. Fate of endocrine-disruptor, pharmaceutical, and personal care product chemicals during simulated drinking water treatment processes. Environ. Sci. Technol. 2005, 39, 6649-6663. [CrossRef]

152. Zhang, S.; Gitungo, S.; Axe, L.; Dyksen, J.E.; Raczko, R.F. A pilot plant study using conventional and advanced water treatment processes: Evaluating removal efficiency of indicator compounds representative of pharmaceuticals and personal care products. Water Res. 2016, 105, 85-96. [CrossRef]

153. Nam, S.-W.; Jo, B.-I.; Yoon, Y.; Zoh, K.-D. Occurrence and removal of selected micropollutants in a water treatment plant. Chemosphere 2014, 95, 156-165. [CrossRef] [PubMed] 
154. Wu, Q.; Shi, H.; Adams, C.D.; Timmons, T.; Ma, Y. Oxidative removal of selected endocrine-disruptors and pharmaceuticals in drinking water treatment systems, and identification of degradation products of triclosan. Sci. Total Environ. 2012, $439,18-25$. [CrossRef] [PubMed]

155. Snyder, S.A.; Adham, S.; Redding, A.M.; Cannon, F.S.; Decarolis, J.; Oppenheimer, J.; Wert, E.C.; Yoon, Y. Role of membranes and activated carbon in the removal of endocrine disruptors and pharmaceuticals. Desalination 2007, 202, 156-181. [CrossRef]

156. Kennedy, A.M.; Reinert, A.M.; Knappe, D.R.; Ferrer, I.; Summers, R. Full- and pilot-scale GAC adsorption of organic micropollutants. Water Res. 2015, 68, 238-248. [CrossRef]

157. Choi, K.J.; Kim, S.G.; Kim, C.W.; Kim, S.H. Effects of activated carbon types and service life on removal of endocrine disrupting chemicals: Amitrol, nonylphenol, and bisphenol-A. Chemosphere 2005, 58, 1535-1545. [CrossRef]

158. McCleaf, P.; Englund, S.; Östlund, A.; Lindegren, K.; Wiberg, K.; Ahrens, L. Removal efficiency of multiple poly- and perfluoroalkyl substances (PFASs) in drinking water using granular activated carbon (GAC) and an-ion exchange (AE) column tests. Water Res. 2017, 120, 77-87. [CrossRef]

159. Wert, E.C.; Rosario-Ortiz, F.L.; Snyder, S.A. Effect of ozone exposure on the oxidation of trace organic contaminants in wastewater. Water Res. 2009, 43, 1005-1014. [CrossRef]

160. Hallé, C.; Huck, P.M.; Peldszus, S. Emerging Contaminant removal by biofiltration: Temperature, concentration, and ebct impacts. J. Am. Water Work. Assoc. 2015, 107, E364-E379. [CrossRef]

161. Zearley, T.L.; Summers, R.S. Removal of trace organic micropollutants by drinking water biological filters. Environ. Sci. Technol. 2012, 46, 9412-9419. [CrossRef]

162. Reungoat, J.; Escher, B.I.; Macova, M.; Argaud, F.X.; Gernjak, W.; Keller, J. Ozonation and biological activated carbon filtration of wastewater treatment plant effluents. Water Res. 2012, 46, 863-872. [CrossRef]

163. Lee, C.O.; Howe, K.J.; Thomson, B.M. Ozone and biofiltration as an alternative to reverse osmosis for removing PPCPs and micropollutants from treated wastewater. Water Res. 2012, 46, 1005-1014. [CrossRef] [PubMed]

164. McKie, M.J.; Andrews, S.A.; Andrews, R.C. Conventional drinking water treatment and direct bio-filtration for the removal of pharmaceuticals and artificial sweeteners: A pilot-scale approach. Sci. Total Environ. 2016, 544, 10-17. [CrossRef] [PubMed]

165. Zhang, S.; Gitungo, S.W.; Axe, L.; Raczko, R.F.; Dyksen, J.E. Biologically active filters-An advanced water treatment process for contaminants of emerging concern. Water Res. 2017, 114, 31-41. [CrossRef] [PubMed]

166. Hollender, J.; Zimmermann, B.G.; Koepke, S.; Krauss, M.; Mcardell, C.S.; Ort, C.; Singer, H.; Von Gunten, U.; Siegrist, H. Elimination of organic micropollutants in a municipal wastewater treatment plant upgraded with a full-scale post-ozonation followed by sand filtration. Environ. Sci. Technol. 2009, 43, 7862-7869. [CrossRef]

167. Broséus, R.; Vincent, S.; Aboulfadl, K.; Daneshvar, A.; Sauvé, S.; Barbeau, B.; Prévost, M. Ozone oxidation of pharmaceuticals, endocrine disruptors and pesticides during water treatment. Water Res. 2009, 43, 4707-4717. [CrossRef]

168. Yates, M.V.; Malley, J.; Rochelle, P.; Hoffman, R. Effect of adenovirus resistance on UV disinfection requirements: A report on the state of adenovirus science. J. Am. Water Work. Assoc. 2006, 98, 93-106. [CrossRef]

169. Rosario-Ortiz, F.L.; Wert, E.C.; Snyder, S.A. Evaluation of UV/H2O2 treatment for the oxidation of pharmaceuticals in wastewater. Water Res. 2010, 44, 1440-1448. [CrossRef]

170. Drewes, J.E.; Anderson, P.; Denslow, N.; Olivieri, A.; Schlenk, D.; Snyder, S.A.; Maruya, K.A. Designing monitoring programs for chemicals of emerging concern in potable reuse-What to include and what not to include? Water Sci. Technol. 2013, 67, 433-439. [CrossRef]

171. Maruya, K.A.; Schlenk, D.; Anderson, P.D.; Denslow, N.D.; Drewes, J.E.; Olivieri, A.W.; Scott, G.I.; Snyder, S.A. An adaptive, comprehensive monitoring strategy for chemicals of emerging concern (CECs) in California's Aquatic Ecosystems. Integr. Environ. Assess. Manag. 2014, 10, 69-77. [CrossRef]

172. U.S. Environmental Protection Agency. Sustainable Futures/P2 Framework Manual-Section 13: Quantitative Risk Assessment Calculations. 2012. Available online: https://www.epa.gov/sustainable-futures/sustainable-futures-p2-framework-manual (accessed on 1 August 2018).

173. Lyman, W.J.; Reehl, W.F.; Rosenblatt, D.H. Handbook of Chemical Property Estimation Methods; American Chemical Society: Washington, DC, USA, 1990; ISBN 0-8412-1761-0.

174. Okochi, H.; Kataniwa, M.; Sugimoto, D.; Igawa, M. Enhanced dissolution of volatile organic compounds into urban dew water collected in Yokohama, Japan. Atmos. Environ. 2005, 39, 6027-6036. [CrossRef]

175. Gros, M.; Petrović, M.; Barceló, D. Development of a multi-residue analytical methodology based on liquid chromatographytandem mass spectrometry (LC-MS/MS) for screening and trace level determination of pharmaceuticals in surface and wastewaters. Talanta 2006, 70, 678-690. [CrossRef] [PubMed]

176. Scheytt, T.; Mersmann, P.; Lindstädt, R.; Heberer, T. Determination of sorption coefficients of pharmaceutically active substances carbamazepine, diclofenac, and ibuprofen, in sandy sediments. Chemosphere 2005, 60, 245-253. [CrossRef] [PubMed]

177. Yamamoto, H.; Nakamura, Y.; Moriguchi, S.; Nakamura, Y.; Honda, Y.; Tamura, I.; Hirata, Y.; Hayashi, A.; Sekizawa, J. Persistence and partitioning of eight selected pharmaceuticals in the aquatic environment: Laboratory photolysis, biodegradation, and sorption experiments. Water Res. 2009, 43, 351-362. [CrossRef] [PubMed]

178. Nakada, N.; Shinohara, H.; Murata, A.; Kiri, K.; Managaki, S.; Sato, N.; Takada, H. Removal of selected pharmaceuticals and personal care products (PPCPs) and endocrine-disrupting chemicals (EDCs) during sand filtration and ozonation at a municipal sewage treatment plant. Water Res. 2007, 41, 4373-4382. [CrossRef] [PubMed] 
179. United States National Library of Medicine. Hazardous Substances Data Bank (HSDB). Available online: http://toxnet.nlm.nih. gov/cgi-bin/sis/htmlgen?HSDB (accessed on 30 March 2018).

180. Huber, M.M.; Canonica, S.; Park, G.-U.; Von Gunten, U. Oxidation of pharmaceuticals during ozonation and advanced oxidation processes. Environ. Sci. Technol. 2003, 37, 1016-1024. [CrossRef] [PubMed]

181. Vieno, N.M.; Härkki, H.; Tuhkanen, T.; Kronberg, L. Occurrence of pharmaceuticals in River Water and their elimination in a pilot-scale drinking water treatment plant. Environ. Sci. Technol. 2007, 41, 5077-5084. [CrossRef]

182. Drori, Y.; Aizenshtat, Z.; Chefetz, B. Sorption-desorption behavior of atrazine in soils irrigated with reclaimed wastewater. Soil Sci. Soc. Am. J. 2005, 69, 1703-1710. [CrossRef]

183. Nkedi-Kizza, P.; Shinde, D.; Savabi, M.R.; Ouyang, Y.; Nieves, L. Sorption Kinetics and Equilibria of organic pesticides in carbonatic soils from South Florida. J. Environ. Qual. 2006, 35, 268-276. [CrossRef]

184. Reungoat, J.; Macova, M.; Escher, B.I.; Carswell, S.; Mueller, J.F.; Keller, J. Removal of micropollutants and reduction of biological activity in a full scale reclamation plant using ozonation and activated carbon filtration. Water Res. 2010, 44, 625-637. [CrossRef]

185. Carballa, M.; Fink, G.; Omil, F.; Lema, J.M.; Ternes, T. Determination of the solid-water distribution coefficient (Kd) for pharmaceuticals, estrogens and musk fragrances in digested sludge. Water Res. 2008, 42, 287-295. [CrossRef]

186. Karnjanapiboonwong, A.; Morse, A.N.; Maul, J.D.; Anderson, T.A. Sorption of estrogens, triclosan, and caffeine in a sandy loam and a silt loam soil. J. Soils Sediments 2010, 10, 1300-1307. [CrossRef]

187. Yamamoto, H.; Hayashi, A.; Nakamura, Y.; Sekizawa, J. Fate and partitioning of selected pharmaceuticals in aquatic environment. Environ. Sci. Int. J. Environ. Physiol. Toxicol. 2005, 12, 347-358. 